Published in final edited form as:

Compr Physiol. 2013 January ; 3(1): 315-330. doi:10.1002/cphy.c120016.

\title{
Iron homeostasis in the liver
}

\author{
Erik R Anderson ${ }^{1}$ and Yatrik M Shah ${ }^{1,2}$ \\ ${ }^{1}$ Department of Molecular \& Integrative Physiology, University of Michigan, Ann Arbor MI. 481109 \\ ${ }^{2}$ Department of Internal Medicine Division of Gastroenterology, University of Michigan, Ann Arbor \\ MI. 481109
}

Abstract

Iron is an essential nutrient that is tightly regulated. A principal function of the liver is the regulation of iron homeostasis. The liver senses changes in systemic iron requirements and can regulate iron concentrations in a robust and rapid manner. The last 10 years have led to the discovery of several regulatory mechanisms in the liver which control the production of iron regulatory genes, storage capacity, and iron mobilization. Dysregulation of these functions leads to an imbalance of iron, which is the primary causes of iron-related disorders. Anemia and iron overload are two of the most prevalent disorders worldwide and affect over a billion people. Several mutations in liver-derived genes have been identified, demonstrating the central role of the liver in iron homeostasis. During conditions of excess iron, the liver increases iron storage and protects other tissues, namely the heart and pancreas from iron-induced cellular damage. However, a chronic increase in liver iron stores results in excess reactive oxygen species production and liver injury. Excess liver iron is one of the major mechanisms leading to increased steatohepatitis, fibrosis, cirrhosis, and hepatocellular carcinoma.

\section{INTRODUCTION}

Iron is an essential micronutrient that is a critical component of oxygen transport proteins (hemoglobin and myoglobin) and of numerous metabolic and redox enzymes. The average adult has 2-4 grams of iron, and over $80 \%$ is contained in hemoglobin of red blood cells (RBC). Chronic iron deficiency results in decreased hemoglobin production and anemia. Systemic iron levels are tightly controlled through an integrative mechanism that involves iron absorption, storage, and recycling. The past decade has been termed "The Golden Age of Iron Biology", due to the significant increase in the understanding of the molecular underpinnings of systemic iron homeostasis (7). When iron regulatory pathways are dysregulated, this leads to either excess tissue iron or iron deficiencies, which affect over a billion people worldwide. Four major cell types or tissues have been shown to be critical for systemic iron homeostasis (figure 1):

\section{Enterocyte}

Dietary iron absorption is tightly regulated in the small intestine. Dietary iron enters the body through absorptive cells in the duodenum. Dietary ferric iron $\left(\mathrm{Fe}^{+3}\right)$ is reduced by the apical ferric reductase duodenal cytochrome $\mathrm{b}(\mathrm{DcytB})$ to ferrous iron $\left(\mathrm{Fe}^{+2}\right)$ and transported into the enterocyte via an apical iron transporter, divalent metal transporter-1 (DMT1, also known as Nramp2, SLC11a2 and DCT1) $(49,69,100,107,109)$. Once iron enters into the cytoplasm through DMT1, iron is either stored or exported by the iron exporter ferroportin (FPN, also known as SLC40A1)(1, 43, 110) located on the basolateral side of the enterocyte. Disruption of DMT1 or FPN leads to inhibition of iron absorption and dysregulation of systemic iron homeostasis $(43,68)$. Following export of iron through FPN, iron is oxidized 
back to the ferric form by the ferroxidase hephaestin and ceruloplasmin ( $\mathrm{Cp}$ ) and loaded onto transferrin (Tf) and circulated through the body (70).

\section{Erythroblast}

A significant portion of circulating Tf-bound iron is utilized in early RBC precursors called erythroblasts for the synthesis of hemoglobin. Hemoglobin comprises of about $95 \%$ of the total cellular protein of the mature RBC and more than $80 \%$ of functional iron in the body is found in hemoglobin (28). Iron is an essential cofactor for the ability of RBCs to transport oxygen, and thus a decrease in body iron levels is the most predominant cause of anemia worldwide.

\section{Macrophage}

Only 1-2 mg per day of dietary iron is required to be absorbed through the intestine. This is due to the highly efficient recycling of iron from senescent erythrocytes. Recycling is performed by splenic and hepatic macrophages. Aging erythrocytes at 120 days old undergo specific changes that can be recognized by macrophages, thus initiating erythrophagocytosis. Iron is recovered from the degradation of hemoglobin and heme by hydrolytic enzymes in the phagocytic vesicles and heme-oxygenase-1 (HO-1) (58). Iron is routed back to circulation through the basolateral iron transporter FPN. Recent studies using macrophage-specific conditional deletion of FPN demonstrate the importance of FPN in exporting iron out of macrophages following erythrophagocytosis $(189,190)$.

\section{Liver}

The liver performs three essential functions in maintaining systemic iron homeostasis: 1) The liver is the major site for production of proteins that maintain systemic iron balance, 2) It is a storage site for excess iron and 3) the liver is critical for the mobilization of iron from hepatocytes to the circulation to meet metabolic requirements. Dysregulation of the liver's ability to maintain balance of these three parameters leads to iron-related disorders. This review will focus on the normal function of the liver in iron homeostasis and the role of liver in iron-related disorders.

\section{PRODUCTION OF PROTEINS FOR IRON HOMEOSTASIS}

(Tf)

Tf is an $80 \mathrm{kDa}$ plasma glycoprotein generated predominantly in the liver (138). However, small amounts are also made in the brain and testis $(14,157)$. Tf is the major serum ironbinding protein and is essential for systemic circulation of iron. Tf consists of two globular lobes of a-helices and $\beta$-sheets, which have a significant amount of homology between the $\mathrm{N}$ - and $\mathrm{C}$ - terminal halves of the molecule. This homology is thought to be due to a gene duplication arising from a $40 \mathrm{kDa}$ ancestral protein containing a single lobe $(3,96-98)$. Each lobe includes metal binding amino acid residues (2 Tyr, $1 \mathrm{His}$, and $1 \mathrm{Asp})$. Tf binds to ferric iron reversibly and with high affinity, but does not bind to ferrous iron $(3,4)$. In addition, Tf can also bind other metals with lower affinity (3). The affinity of iron is also regulated by $\mathrm{pH}$, as iron binding to $\mathrm{Tf}$ decreases as the $\mathrm{pH}$ drops, with no detectable amounts observed below $\mathrm{pH} 4.5(3,4)$. The reversible binding of iron to Tf is important and allows it to be a cellular iron donor or iron acceptor depending on the systemic requirements of iron.

(Cp)

$\mathrm{Cp}$ is a copper-dependent serum ferroxidase which works in tandem with FPN for cellular iron export into circulation $(129,130)$. Cellular iron is usually in the ferrous form and is exported out of the cell by FPN, however the affinity of $\mathrm{Tf}$ for ferrous iron is relatively weak 
and $\mathrm{Cp}$ is required to oxidize iron to its ferric form, which binds with high affinity to $\mathrm{Tf}$ $(129,130)$. Disruption of $\mathrm{Cp}$ in mouse models further supports the role of $\mathrm{Cp}$ in systemic iron homeostasis $(30,70)$.

\section{Ferritin}

Ferritin is a multi-subunit protein that consists of a heavy and light chain. Ferritin from different tissues can vary in the ratio of heavy compared to light chains. Liver ferritin contains mainly the light chain and can store up to 4500 atoms of iron. Hepatocytes are the major site for ferritin synthesis, however most cells that have been assessed can synthesize ferritin to a smaller degree $(12,167)$. Cells with high iron levels are capable of an adaptive increase in ferritin synthesis. Both ferritin subunit synthesis are controlled through a posttranscriptional mechanism by the iron response element (IRE)/iron regulatory protein (IRP) system. The ferritin mRNAs contain a single IRE in the 5' UTR. Under iron deficient conditions, the IRPs bind to this IRE and repress translation. However, as intracellular iron increases in a cell, the repression is relieved and ferritin synthesis is increased. For more details of the IRE/IRP system, refer to the comprehensive review by Muckenthaler, M.U et al. (113). Although the IRP/IRE regulation of ferritin synthesis is the predominant pathway that allows an adaptive increase, several other mechanisms, such as IL-1, TNFa, hypoxia, and oxidative stress have also been observed to regulate ferritin expression $(23,169,170$, $173,184)$. It is likely that a combination of these pathways allow an efficient increase in ferritin when required.

\section{Hepcidin}

Hepcidin is a 25 amino acid antimicrobial peptide that is produced in hepatocytes and secreted into the circulation (91). Hepcidin is translated as an 84 amino acid pro-protein, and cleaved by the pro-hormone convertase furin to produce the active peptide (175).

Subtractive hybridization experiments between iron loaded and control mouse livers initially identified hepcidin as an iron-regulated protein (136). The role of hepcidin in iron homeostasis was further confirmed when hepcidin was inadvertently disrupted in addition to USF2 and these mice were severely iron overloaded (119). The effect of hepcidin knockout on iron homeostasis was confirmed in a subsequent paper, which showed that animals deficient in hepcidin, but having normal USF2 expression developed severe hemochromatosis (101). Conversely, animals that overexpress hepcidin in the liver demonstrate severe iron-deficiency anemia (120). A clue to the function of hepcidin was discovered after subjecting rats to an iron-deficient diet. Following iron deficiency, rats rapidly repress liver hepcidin and upregulate the intestinal iron transporters DMT1, DcytB, and FPN (54). Hepcidin was believed to regulate iron homeostasis due to an interaction with iron transporters. A breakthrough came when the hepcidin receptor was discovered. Through careful in vitro analysis, it was determined that hepcidin binds to FPN which leads to its internalization and proteasomal degradation (117). Hepcidin is increased in iron loading, which leads to a decrease in duodenal iron absorption to normalize iron levels. In the case of iron deficiency, hepcidin is repressed which allows more iron to be transported from the enterocyte to the serum (figure 2). In addition, FPN is increased in macrophages following erythrophagocytosis, and hepcidin represses FPN in these cells (89). In macrophages during iron loading, hepcidin decreases iron transport following iron recycling from senescent RBCs. Whereas during iron deficiency, a significant increase in iron efflux would be expected following erythrophagocytosis (figure 2). In addition to iron levels resulting in the regulation of hepcidin levels, hypoxia and erythropoiesis are major repressors of hepcidin expression. This provides a novel link between oxygen homeostasis and iron levels. Moreover, inflammation is a major activator of hepcidin expression. This results in restriction of serum iron levels during an infection, and therefore is less conducive for growth of pathogenic bacteria. The last decade has shown the importance of hepcidin as the 
master regulator of both duodenal iron absorption and red blood cell (RBC) iron recycling. Studying the regulation of hepcidin expression in the liver has been a priority for understanding regulation of systemic iron homeostasis. The transcriptional regulation of hepcidin has been reviewed elsewhere $(56,114)$ and is summarized in figure 3 . Here, we only briefly mention a few major pathways that are critical in hepcidin regulation. In addition to the major pathways, several other accessory proteins have been identified, which are mutated in iron-related disorders. Their importance in hepcidin regulation is covered in more detail below in the liver iron overload and anemia section.

SMAD/ bone morphogenetic protein (BMP) signaling-A key finding in the regulation of hepcidin is the essential role of the BMP-SMAD signaling cascade. BMPs are ligands that belong to the transforming growth factor- $\beta$ (TGF- $\beta$ ) superfamily. BMPs bind to type I and type II serine threonine kinase receptors, which phosphorylate specific intracellular SMAD proteins (SMAD1/5/8). Phosphorylated SMAD1/5/8 (P-SMAD1/5/8) binds to the common mediator SMAD4, and the SMAD complex translocates to the nucleus to modulate transcription of target genes. BMPs, but not TGF- $\beta$ signaling induced hepcidin expression in cultured liver cell lines and in vivo (11). Several BMPs signal through SMAD activation, however BMP6 is the endogenous ligand that modulates hepcidin expression. BMP6 knockout mice have decreased hepcidin expression and an increase in tissue iron (8, 10, 11, 111). BMP6 knockout mice still have the ability to increase hepcidin expression following inflammatory stimuli. The importance of SMAD signaling in hepcidin regulation was demonstrated in mice with a hepatocyte-specific disruption of SMAD4. A near complete loss of hepcidin expression was observed in these mice and eventually the mice die of severe iron overload in multiple tissues (183). Interestingly, liver SMAD4 knockout mice are unable to increase hepcidin expression in response to iron loading, suggesting that SMAD4 mediates the response of hepcidin to changes in systemic iron requirements. Signaling through the BMP receptor leads to SMAD1/5/8 phosphorylation, which is required for SMAD4 transcriptional activity (6). The regulation of hepcidin by iron loading and iron deficiency is correlated with phosphorylation of the SMAD1/5/8 proteins. In iron deficiency, pSMAD1/5/8 is decreased dramatically, and is substantially increased in conditions of iron overload (85).

STAT3 and inflammatory pathways-Hepcidin is induced in response to inflammatory stimuli $(57,118)$. Hepcidin induction by inflammation leads to iron sequestration, which can decrease bacterial growth. However, chronic diseases are associated with anemia (150). The mechanism for the induction of hepcidin by inflammation is mediated by IL-6 in cultured cells, mice, and humans (115). Subsequently, it was shown that IL-6 regulates expression of hepcidin by inducing STAT3 binding to the hepcidin promoter $(176,185)$. To support this, it was shown that anti-IL-6 receptor antibody improves anemia of inflammation (158).

Hypoxia and erythropoietic pathways-Hypoxia, or low oxygen tension, is a physiological condition that results in numerous adaptive changes in gene expression. Hypoxia represses hepcidin expression both in cultured cells and in mice (121). Many mechanisms have been proposed to play a role in hypoxic hepcidin repression $(29,31,94$, 134, 179). Hypoxia-inducible factor (HIF) is the major transcription factor activated following hypoxia and HIF is thought be critical in the hypoxia-mediated repression of hepcidin (20). HIF was shown to bind directly to the hepcidin promoter resulting in repression (134). However, recent studies refute these findings $(108,179)$. It has been reported that hypoxia through a HIF2a mediated increase in erythropoiesis is the critical pathway leading to hepcidin repression (108). Interestingly, a mutation that leads to HIF stabilization causes Chuvash polycythemia. In these patients a decrease in hepcidin expression is observed without a significant association with erythropoiesis (65). There is no 
clear mechanism that mediates hepcidin repression during hypoxia, and this is an active area of study

Erythropoiesis is a well-characterized pathway leading to hepcidin repression. In several mouse models that induce erythropoiesis, a significant decrease in hepcidin is observed (16, $53,61)$. The decrease in hepcidin allows the increase of iron required for RBCs during erythropoiesis. In a model of intensive care anemia, erythropoietin injections or phlebotomies were able to repress hepcidin expression despite high levels of IL-6, which is known to strongly increase hepcidin expression (99). Similarly, hypoxia is able to repress hepcidin expression under conditions of high IL-6. One of the mechanisms by which erythropoiesis represses hepcidin is through erythropoietin (EPO) binding to its receptor in hepatocytes, which leads to downregulation of C/EBPa and hepcidin repression (137). C/ EBPa is a liver-enriched transcription factor that is important in hepcidin regulation. Mice with a liver specific deletion of C/EBPa have low levels of hepcidin expression (35). However, erythropoietic blockers prevented the suppression of hepcidin (178), suggesting an EPO-independent erythropoietic derived mechanism is responsible for the decrease in hepcidin. Growth differentiation factor 15 (GDF15) and twisted grastrulation 1 (TWGS1) are secreted during erythroblast maturation and can inhibit hepcidin expression $(165,166)$. However, their role in hepcidin repression during erythropoiesis is still unclear $(9,82)$.

\section{LIVER IRON IMPORT}

\section{Tf-bound iron}

The major mechanism for iron uptake in the liver and most other tissues is through the $\mathrm{Tf} /$ transferrin receptor (Tfr) system (figure 4). Tf as discussed above is a constitutively expressed protein. Tfr1 transcript stability is regulated by the IRP/IRE system. Unlike ferritin, which has a single IRE in its 5' UTR, Tfr1 transcript contains several IREs in its 3' UTR. IRPs bind to the IRE in the Tfr1 transcript, which increases mRNA stability (77). Under low iron conditions more Tfr1 is translated allowing for increased iron uptake through Tf. Under conditions of high iron the IRPs are inactivated that leads to decreased Tfr1 mRNA stability and decreased iron uptake. Iron circulates bound to Tf. When both lobes are occupied with iron (Diferric Tf), this complex binds with high affinity to Tfr1 (3, 4). Diferric Tf-TFR1 binding activates cellular iron uptake by receptor-mediated endocytosis, and this pathway is a model system to study the precise mechanisms of receptor-mediated endocytosis $(15,32,33,95)$. Diferric Tf internalization into endocytic vesicles initiates the release of iron from $\mathrm{Tf}$ via acidification of endosomes $(36,72)$. Ferric iron is reduced to ferrous iron by an endosomal ferric reductase (126). Through a positional cloning strategy a transmembrane protein Steap3 was found to be a critical reductase in the endosome. Mutations in the steap3 gene lead to microcytic anemia (126). Steap3 is highly expressed in the hematopoietic cell lineage, but the role of steap3 in other cell types is not clear. However, there are three other family members (Steap1, 2, and 4) that also contain ferric reductase activity (127). Ferrous iron is then transported to the cytosol via DMT1, which in addition to being localized on the brush border cells of the small intestine, is also observed on recycling endosomes $(25,67)$. Interestingly, mice that lack DMT1 are still capable of accumulating hepatic iron, suggesting that DMT1 is not essential for Tf-bound iron uptake or other transporters have a redundant role (68). ZIP14, a family member of the ZIP metal transporters is also localized to endosomes and is important for the movement of iron from endocytic compartment to the cytosol (191). Following iron transport to the cytosol $\mathrm{Tf}$ and $\mathrm{Tfr} 1$ are recycled back to circulation and to the cell membrane, respectively $(15,32,33,95)$.

Non-transferrin bound iron (NTBI) - In cases of severe iron overload, the level of iron will exceed the capacity of $\mathrm{Tf}$, and there is a greater ratio of iron in the plasma that occurs as 
NTBI. NTBI is bound by a number of non-protein ligands including citrate which is likely to be the predominate form of plasma NTBI found in hemochromatosis $(21,66)$. The liver uptake of ferric citrate involves dissociation of citrate and transport of iron into the hepatocyte (figure 4). NTBI is efficiently taken up by hepatocytes and the uptake is not downregulated by excess iron in the liver as observed with Tf-bound iron through the IRE/ IRP system. Several mechanisms have been shown to contribute to NTBI uptake including membrane bound DMT1 and ZIP14 facilitating direct uptake of iron into the hepatocytes $(105,154)$. In addition, several other mechanisms are capable of NTBI transport into the cells. L-type calcium channels facilitate transport of NTBI into cardiac myocytes. Calcium channel blockers inhibit NTBI uptake into the heart (131). Lipocalin 2 is a multi-functional protein, which has iron-sequestering properties and is critical in binding to siderophores and limiting iron to pathogenic bacteria (51). However, some data suggest that lipocalin 2 could meditate NTBI uptake (83). Scara5 is a ferritin receptor that mediates NTBI uptake into the kidney (103). However, the role of these pathways for hepatic NBTI uptake is not clear.

Heme and hemoglobin associated iron-The liver also has the capacity to acquire iron from heme or hemoglobin (figure 4). These pathways under normal conditions contribute to a negligible amount of iron uptake in the liver. However, during hemolysis this could lead to a substantial amount of heme or hemoglobin being taken up by the liver. In several diseases such as hemolytic anemia, gram-positive bacterial infection, and malaria, increased hemolysis leads to excess hemoglobin and heme. The liver derived scavenging proteins, haptoglobin and hemopexin rapidly sequesters free hemoglobin and heme.

Haptoglobin and hemopexin proteins bind with high affinity to free hemoglobin and heme, respectively $(79,168)$. Once sequestered, the haptoglobin-hemoglobin complex binds to CD163, which is highly expressed on mature tissue macrophages, including Kupffer cells (92). The hemopexin-heme complex binds to LRP/CD91, which is expressed in several cell types, including macrophages and hepatocytes (78). Following binding to their respective receptor the complex is endocytosed and degraded through a lysosomal pathway. Iron is released from heme by the HO- 1 and enters the same intracellular pool as iron from other sources as mentioned above.

\section{LIVER IRON STORAGE}

Regardless of the source, iron that enters the hepatocyte enters the same intracellular pool. This pool of iron is stored, mobilized for systemic metabolic demands, used in intracellular enzymes, or used in mitochondrial iron sulfur proteins. Since free intracellular iron is toxic, the majority of iron in the cells is stored in ferritin, which is discussed above in more detail. Within the liver all cell types can store iron, but under normal conditions hepatocytes represent the major storage site. During severe iron overload, as the ferritin storage becomes saturated, storage in hemosiderin is elevated. Hemosiderin is an insoluble complex made up of degraded ferritin and large ferric hydroxide chains. Iron stored in hemosiderin is poorly mobilized $(104,149)$.

\section{LIVER IRON EXPORT}

Iron export from the liver, both in Kupffer cells and hepatocytes, is unclear and far less is known about the molecular mechanisms as compared to iron uptake and storage in the liver. Iron that is stored in ferritin has the ability to be mobilized from the liver during times of high systemic demand of iron. This is the rationale for therapies of patients with hemochromatosis (discussed in more detail below). Patients with high liver iron are periodically bled initiating mobilization of iron from the liver to circulation. Rodent studies using radioactive iron tracers estimate that up to $6 \%$ of iron is released from hepatocytes daily (13). Several cues have been shown to regulate iron mobilization from the liver. 
Erythropoiesis and a systemic change in iron levels in rats increase the mobilization. Iron export is inhibited following inflammation. In addition, the Kupffer cells also contribute significantly to iron release from the liver via erythrophagocytosis and release of iron from RBCs (13). The first step in iron mobilization is the regulated release of iron from ferritin. This is thought to be an autonomous property of ferritin controlled by cytosolic iron levels $(38,142)$. Expression of FPN in cells increases iron release from ferritin (117). The only known iron exporter is FPN, which has been shown to be critical for iron transport in animals (43). FPN is expressed highly in macrophages and to a lesser degree in hepatocytes (144). As mentioned above, FPN is regulated by hepcidin-mediated binding and degradation. This pathway is well characterized in in vitro cell systems. However, the role hepcidin plays in regulating hepatic FPN protein stability in vivo is not clear. FPN is also regulated by the IRE/IRP system, and has an IRE in its 5' UTR. Under conditions of cellular iron deficiency, IRP proteins bind to the IRE in the FPN transcript, blocking its translation. This leads to decreased protein expression of FPN on the membrane and allows the cell to retain iron through decreased export (113). Recent conditional disruption studies underscore the importance of FPN in the liver. Macrophage-specific deletion of FPN led to iron sequestration in Kupffer cells. The deletion did not have a profound affect on RBC parameters and only mild anemia was observed (189). This finding is quite surprising since most of the iron for daily requirements is derived from macrophage-mediated recycling of senescent RBCs. These data suggest there must be compensatory mechanisms when macrophage iron export is ablated. A hepatocyte-specific FPN deletion led to mild iron sequestration in hepatocytes. However, RBC parameters were normal. Under low iron conditions these mice developed anemia; RBC and hemoglobin values were significantly lower (190).

\section{LIVER IRON OVERLOAD}

The liver is central to iron homeostasis and depends on a complex feedback mechanism between body iron requirements, intestinal absorption, and recycling from senescent RBCs. Dysregulation of these mechanisms can lead to iron overload. This section will discuss common and rare disorders of iron overload.

\section{Hereditary Hemochromatosis $\mathbf{( H H )}$}

HH is a genetic disorder and a common cause of iron overload. 1 in 200 will be affected by this disorder (128). It was first described by Armand Trousseau in 1865 and was referred to as bronze diabetes. A change in the hue of the skin, liver, and pancreas was observed, although the cause was not known at this time. Over 30 years later Von Recklinghausen named this condition hemochromatosis following further analysis showing iron accumulation in liver cells. In 1996 it was identified that a mutation in the HFE gene was associated with $\mathrm{HH}$ (46). It is now known that $\mathrm{HH}$ is an autosomal recessive disorder and 1 in 8 people in the United States have a mutation in a single copy of the gene (128). Further study of patients with $\mathrm{HH}$ has led to the identification of several other iron regulatory genes that cause $\mathrm{HH}$. These genes demonstrate that iron sensing and regulation of hepcidin is a concerted effort of several proteins. All HH disorders demonstrate a dysregulation in the hepcidin-FPN homeostasis, and are classified into 5 types.

Type 1-High FE (HFE) encodes an atypical major histocompatibility complex protein, and mutations in this gene are the most common cause of $\mathrm{HH}$ (46). The most common mutation observed is a missense mutation of cysteine 282 to tyrosine (Cys282Tyr) (152). However, several other mutations are characterized leading to iron overload (152). HFE mutations that lead to iron overload are associated with a significant decrease in hepcidin expression. Consistent with these data, mouse models which are deleted for HFE or have a 
knock-in Cys282Tyr mutation also have iron overload and a decrease in hepcidin expression (102). Since HFE is abundant in several tissues including enterocytes and liver, a conditional disruption of HFE in the liver and intestine was generated. In this study, hepatocyte-specific disruption of HFE recapitulated a similar phenotype as the whole body knockout mouse model, characterized by iron overload and decrease in hepcidin expression (180). Mice with HFE disruption in the intestine were similar to normal controls (181). These data demonstrate that HFE in the hepatocytes is critical for iron homeostasis. The molecular function of HFE and its precise role in regulating hepcidin expression has been a subject of great interest. Several lines of evidence suggest that HFE binding to Tfr1 and Tfr2 may be the mechanism by which HFE regulates hepcidin expression $(60,153)$. Mutations in HFE that increased binding to Trf1 blocked hepcidin expression. Mutations that weakened HFE and Tfr1 interaction increased hepcidin expression (153). In addition, HFE and Tfr2 interact and disruption of Tfr2 leads to decreased hepcidin expression $(50,86,116)$. Lastly HFE and $\mathrm{Tfr} 2$ interaction is required for regulation of hepcidin by iron containing $\mathrm{Tf}(60)$. Together the data suggest a mechanism where Tf binding to Tfr1 releases HFE, which then can bind to Tfr2 and stabilize its protein expression leading to an increase in SMAD signaling (figure 3).

Type 2A-Juvenile hemochromatosis $(\mathrm{JH})$ is a rare autosomal recessive disorder of iron overload and symptoms become apparent before the age of 30 . JH leads to organ damage, and usually causes cardiomyopathy, hypogonadism, liver injury, and diabetes. JH is a caused by mutations in the gene for HFE2 which encodes the hemojuvelin (HJV) protein $(132,152)$. HJV is a glycophosphatidylinositol anchored membrane protein. Several HFE2 mutations have been found in patients. However, the glycine 320 to valine is the most frequent mutation that is reported (152). To confirm that HJV is causative in this type of hemochromatosis, an HJV knockout mouse model was generated (125). This mouse model demonstrates severe iron overload associated with very low levels of hepcidin expression, similar to that observed in patients with HJV mutations (132). Hepcidin expression was appropriately increased in response to inflammatory stimuli, suggesting that HJV is involved in iron sensing but does not play a role in hepcidin regulation during inflammation. The early onset of iron overload in $\mathrm{JH}$ is due to a robust repression of hepcidin. In $\mathrm{HH}$ due to HFE mutations there is only a moderate decrease in hepcidin expression leading to iron overload that is symptomatic at later ages. HJV is expressed in several tissues, and in the liver HJV primarily expressed in hepatocytes. Restoring HJV expression in hepatocytes of HJV knockout mice completely restored hepcidin expression and ablated the iron overload (188). Further mechanistic studies demonstrated that HJV functions as a BMP co-receptor and is important for induction of hepcidin expression in response to BMP signaling (10). HJV binds to BMPs and enhances the activity of the SMAD signaling cascade (10).

Type 2B-Similar to HJV mutations, mutations in the HAMP gene, which encodes for hepcidin, are a very rare cause of JH. Currently 12 known mutations occur on the HAMP gene leading to a decrease in the normal production of hepcidin (74). Since hepcidin function or expression is dramatically diminished, the iron overload symptoms are observed before the age of 30 .

Type 3-Tfr2 mutations lead to an autosomal recessive iron overload disease similar to HFE related-HH phenotype. Tfr2 as mentioned above is capable of binding to HFE and this interaction is critical in maintaining hepcidin expression (60). Unlike Tfr1, which is ubiquitously expressed, Tfr2 is expressed only in hepatocytes and erythroid precursors (87, 159). Tfr 2 cannot compensate for the loss of Tfr1 (171). The knockout mouse model and the liver-specific disruption of Tfr2 confirm its importance in regulating hepcidin levels (86, 182). Hepcidin levels are decreased significantly in these mouse models compared to 
littermate controls, and tissue iron is increased. The most common mutation observed is in amino acid 245, which is converted into a stop codon resulting in a protein product that is not expressed (24). As mentioned above, Tfr2 binding to HFE promotes SMAD activation and hepcidin expression. Upon its deletion this signaling pathway is decreased causing a significant drop in hepcidin levels.

Type 4-SLC40a1 is the gene that encodes for the iron exporter FPN. FPN is the target of hepcidin, which causes rapid internalization and degradation of FPN (117). More precise work on the mechanism of FPN degradation by hepcidin demonstrates that following hepcidin binding, FPN is phosphorylated on tyrosine residues, which lead to its endocytic shuttling and degradation by the proteasome pathway (39). JAK2 is the critical kinase phosphorylating FPN (37). However, recent data demonstrate that both phosphorylation of FPN and JAK2 are not essential for FPN degradation (141, 148). Mutations in HFE, HJV, hepcidin, and Tfr2 are all recessive mutations. However, mutations in FPN are dominant. Patients that are heterozygous for the mutation develop the disease. This is due to FPN functioning as a dimer and the mutant protein can act as a dominant negative $(40,41)$. Several mutations of FPN have been observed. Detailed molecular studies demonstrate that the mutations inhibit proper membrane localization of FPN, inhibit the export function of FPN, disrupt hepcidin binding, or inhibit FPN internalization (84). Therefore, depending on the mutation in FPN the patients can present with very different phenotypes. Mutations that inhibit membrane localization or export function can lead to macrophage iron overload. While those mutations that inhibit hepcidin binding or hepcidin-meditated internalization lead to continuous export of iron into serum and eventually iron overload in the hepatocytes.

\section{Secondary hemochromatosis}

Secondary hemochromatosis is the result of another disease, which causes excess liver iron loading. Most of diseases that lead to secondary hemochromatosis are acquired disorders of erythropoiesis (63). The most common causes of secondary hemochromatosis are listed in table 1. A well-studied disorder that leads to secondary hemochromatosis is $\beta$-thalassemia. $\beta$-Thalassemia is a congenital blood disorder due to mutations in the $\beta$-globin gene leading to a partial or complete loss of $\beta$-globin synthesis resulting in $\beta$-thalassemia intermedia and Cooley's anemia, respectively. The decrease in $\beta$-globin results in ineffective erythropoiesis and erythropoietic stress. Persons with $\beta$-thalassemia intermedia have mild anemia with a slight lowering of hemoglobin levels in the blood. In most cases treatment is not necessary, but severe patients with low hemoglobin levels will need occasional blood transfusions (161). Cooley's anemia results in a striking deficiency in hemoglobin production. Patients will need frequent blood transfusions (161). The blood transfusions lead to dysregulation of the systemic iron homeostasis since donor blood is a rich source of iron. The body cannot eliminate the excess iron efficiently, leading to increased tissue iron. Regular blood transfusions are the most common cause of secondary hemochromatosis (63). Initially it was thought that the iron overload was primarily due to regular blood transfusions. However, mouse models of $\beta$-thalassemia hyperabsorb iron. This is the major mechanism leading to iron overload in $\beta$-thalassemia intermedia and significantly contributes to the tissue iron overload in Cooley's anemia $(76,164,186)$. It is less clear whether an increase in iron absorption plays a significant role compared to blood transfusions in other disorders of erythropoiesis listed in table 1 . However, recent work has shown that effective and ineffective erythropoiesis can stimulate iron absorption, therefore this mechanism of iron overload may be true for other diseases leading to secondary hemochromatosis (5). Increased iron absorption in secondary hemochromatosis may be due to an increase intestinal hypoxia signaling and a decrease in hepcidin expression $(5,133)$. Increasing hepcidin levels in mouse models of $\beta$-thalassemia improved liver iron loading and anemia (62). 


\section{Aceruloplasminemia, hypotransferrinemia, and DMT-1 deficiency}

Aceruloplasminemia, hypotransferrinemia, and DMT1 deficiency are causes of secondary hemochromatosis, but are not disorders of erythropoiesis; rather these disorders are due to ineffective transport of iron. Aceruloplasminemia is due to a loss-of-function mutation in $\mathrm{Cp}$ and is inherited in an autosomal recessive manner. Iron overload in aceruloplasminemia is mainly observed in the brain and liver $(73,187)$. A similar phenotype is also observed in $\mathrm{Cp}$ knockout mouse models. Hypotransferrinemia is an autosomal recessive disorder leading to loss of Tf production. Hypotransferrinemia is associated with severe microcytic anemia, and an adaptive increase in iron absorption, which leads to severe liver iron loading $(64,75)$. Consistent with hypotransferrinemic patients, the hpx mouse, which produces no Tf has liver iron overload and anemia (171). DMT1 deficiency is an autosomal recessive disorder leading to increase in liver iron (80). This is thought to be due to the role of DMT1 in iron export from the endocytic compartment.

\section{Dysmetabolic iron overload syndrome (DIOS)}

DIOS is a newly characterized secondary hemochromatosis disorder. DIOS is associated with features, such as obesity, type 2 diabetes, alcohol use, and chronic hepatitis $C(42,81$, $106,139)$. This is now the most common cause of iron overload observed in patients. The iron overload is observed in $15 \%$ of patients with metabolic syndrome, $50 \%$ in patients with non-alcoholic fatty liver disease, over $40 \%$ of patients with chronic hepatitis $\mathrm{C}$ infection, and significant number of patients with alcoholic liver disease $(18,81,139,174)$. Currently the mechanisms, which contribute to DIOS are unclear. However, a significant decrease in FPN gene expression has been noted in patients with DIOS (2).

\section{IRON-INDUCED LIVER DAMAGE}

High levels of iron deposition lead to tissue damage and dysregulation of function. In the liver increased free iron if untreated, leads to fibrosis and cirrhosis, and can increase morbidity and mortality $(123,124,145)$. Hepatic tissue injury is directly correlated to the duration and amount of iron loading $(123,124)$. Cells normally produce basal levels of reactive oxygen species (ROS) through metabolic function of the mitochondria and other organelles. ROS are kept at low basal levels by several antioxidant enzymes, and low levels of ROS are important in normal cell physiology (146). ROS in conjunction with high cellular iron results in a robust increase of hydroxyl radicals, which leads to cell damage. Free iron generates ROS through the Fenton and Haber-Weiss reactions (figure 5). The superoxide radical $\left(\mathrm{O}_{2}{ }^{-}\right)$reduces ferric iron to ferrous iron, which reacts with hydrogen peroxide $\left(\mathrm{H}_{2} \mathrm{O}_{2}\right)$ to generate highly reactive hydroxyl radicals $\left(\mathrm{OH}^{\circ}\right)(90)$. Hydroxyl radicals lead to an increase in peroxidation of phospholipids within organelle and cellular membranes, oxidation of amino acid side-chains, DNA strand breaks, and protein fragmentation. The exact mechanisms by which high intracellular iron leads to liver fibrosis and cirrhosis are unclear, but iron-induced cellular damage has been shown to directly increase hepatocyte cell death and activate Kupffer and stellate cells $(135,160)$ (figure 6). More recently, clinical evidence suggests that high liver iron could play a role in insulin resistance $(45,143)$. The increase in iron-induced ROS in Kupffer cells can initiate a proinflammatory cascade in the liver. Increased ROS production activates NF- $\kappa \mathrm{B}$ signaling leading to an increase in IL-6, TNF- $\alpha$, and IL-1 $\beta$ in the liver $(22,112)$. Liver inflammation can lead to hepatic insulin resistance, which is a major pathway leading to hyperglycemia in type II diabetes (55). Lastly, liver iron overload increases the risk for hepatocellular carcinoma (HCC). HCC is the major life threatening complication associated with hereditary hemochromatosis (124). Several studies have looked at the risk factor for HCC in hereditary hemochromatosis patients and some have estimated the risk to be 100-200 fold higher in $\mathrm{HH}$ patients $(19,162)$. In addition, other iron overload disorders such as thalassemia are 
associated with an increased risk for HCC (17). The increase in iron plays an active role in HCC pathogenesis. Chelation of iron or placing mice on an iron deficient diet decreases tumor growth $(71,151)$.

\section{TREATMENT OF IRON OVERLOAD}

In patients with $\mathrm{HH}$, phlebotomy is used to decrease liver iron. Regular bleeding of the patients leads to an increase in erythropoiesis, which mobilizes liver iron stores to meet the demand for iron that is required to generate mature RBCs (59). Secondary hemochromatosis is also associated with severe anemia, thus phlebotomy is not an option. In these patients iron chelators are used to decrease liver iron (59). Deferoxamine has been used for over three decades for iron chelation. More recently two new iron chelators have also been used, deferiprone and deferasirox (93). Iron chelators have been shown to be effective in decreasing liver iron and also morbidity and mortality associated with iron overload. Several rounds of phlebotomy and/or administration of iron chelators are required; these are slowacting treatment options and may not successfully decrease the liver injury associated with an increase in iron. Alternatives to existing treatments are needed. Recently, hepcidin has been shown to be a very attractive target and good proof of principles studies have been done. Several studies in mouse models of HH have shown that increasing hepcidin levels can ameliorate the iron overload $(122,177)$. Recently in $\beta$-thalassemia models, increasing hepcidin expression resulted in decreased liver iron (62). Currently several strategies are being assessed to increase hepcidin levels. The specific sites that are required for hepcidinFPN binding are known. Precise structural mutagenesis studies have demonstrated that nine amino acids of hepcidin are critical for the binding to FPN and initiating its internalization (140). Modifications of these nine amino acids has led to several peptides that have increased activity over full length hepcidin. Moreover, the modified hepcidin derived peptides are functional in vivo and can prevent iron overload that is observed in hepcidin knockout mice (140). These agents are stable orally and may provide a well-tolerated form of treatment for hereditary and secondary hemochromatosis. Other approaches may also be useful in increasing hepcidin expression (59). Treatment with BMP6 increases hepcidin expression in HFE-null mouse model and prevents iron overload (34). Moreover, since hepcidin regulatory pathways are well characterized, several possibilities such as SMAD, C/ EBPa, and STAT3 activators could have potential roles in increasing hepcidin expression in vivo.

\section{ANEMIA}

On the other end of the spectrum, aberrant upregulation of hepcidin is critical in the pathogenesis of anemia of chronic disease, which encompasses several diseases including kidney disease, inflammatory disease, cancer, and aging (26). In healthy human volunteers and mice, studies demonstrate that inflammatory agents cause a robust and rapid decrease in serum iron levels $(27,88,115,147)$. Within hours following induction of inflammation, hepcidin levels are significantly elevated. The decrease in serum iron is due to hepcidinmediated internalization of FPN leading to iron sequestration in macrophages. This is thought to be a protective mechanism that limits iron available to infectious pathogens. However, in chronic disorders this leads to anemia, which can have detrimental effects in the primary disease pathogenesis. Similarly, in most cancers there is a decrease in serum iron levels and increased anemia (156). The decrease in iron is suggested to be beneficial in limiting tumor growth. The mechanism may vary depending on the primary disease. However, the IL-6-STAT3 pathway is critical in increasing hepcidin expression during inflammation (163). The best treatment for anemia of chronic disease is resolving the primary chronic disease. In severe cases, blood transfusion, EPO, or intravenous administration of iron is used (163). In addition to an increase in hepcidin expression from 
chronic disorders, rare genetic mutations in the TMPRSS6 gene cause an increase in hepcidin expression and iron-refractory iron deficiency anemia (IRIDA) (47). This was further confirmed in the TMPRSS6 knockout mice, which had hair loss and microcytic anemia associated with high levels of hepcidin expression (48, 52). A similar finding was noted in the mask mutant mouse strain, characterized by a premature stop codon in the TMPRSS6 gene (44). IRIDA is iron deficiency anemia that is unresponsive to oral iron therapy. TMPRSS6 (also known as matriptase-2) encodes a type II transmembrane serine protease, which is expressed predominantly in the liver. The first substrate that was characterized for TMPRSS6 was HJV. The serine protease of TMPRSS6 cleaves membrane HJV, leading to downregulation of hepcidin expression (155). Mutations in TMPRSS6 decrease its protease activity leading to increased protein expression of $\mathrm{HJV}$ and a coordinate increase in hepcidin expression.

\section{CONCLUSION}

The liver is the central tissue which regulates systemic iron homeostasis by acting as a sensor and regulator of iron levels. In addition, through its role in iron storage, the liver can protect more sensitive tissues from iron-induced cellular injury. The past decade has led to several novel liver-derived players regulating systemic iron homeostasis and identification of new mutations in iron-related disorders. Several pathways in the liver regulate hepcidin, the master hormone for maintaining systemic iron homeostasis. Recent studies have shown that these pathways can have redundancy or act independently based on the stimuli (172). The challenge will be to understand how these pathways crosstalk and are regulated in a coordinate manner to maintain hepcidin levels. Moreover, how can these pathways be targeted in iron-related disorders that could be of therapeutic benefit? Targeted therapies for iron related disorders are actively being pursued such as the case for hepcidin mimetics and BMP agonists, and the coming decade should yield novel therapies.

\section{Acknowledgments}

This work was supported by grants to Y.M.S from the National Institutes of Health (CA148828 and DK095201), The University of Michigan Gastrointestinal Peptide Center, and Jeffrey A. Colby Colon Cancer Research and the Tom Liu Memorial Funds of the University of Michigan Comprehensive Cancer Center. E.R.A is supported by the Rackham Predoctoral Fellowship, University of Michigan.

\section{REFERENCES}

1. Abboud S, Haile DJ. A novel mammalian iron-regulated protein involved in intracellular iron metabolism. J Biol Chem. 2000; 275(26):19906-19912. [PubMed: 10747949]

2. Aigner E, Theurl I, Theurl M, Lederer D, Haufe H, Dietze O, Strasser M, Datz C, Weiss G. Pathways underlying iron accumulation in human nonalcoholic fatty liver disease. The American journal of clinical nutrition. 2008; 87(5):1374-1383. [PubMed: 18469261]

3. Aisen P, Brown EB. Structure and function of transferrin. Progress in hematology. 1975:925-56.

4. Aisen P, Leibman A, Zweier J. Stoichiometric and site characteristics of the binding of iron to human transferrin. J Biol Chem. 1978; 253(6):1930-1937. [PubMed: 204636]

5. Anderson ER, Xue X, Shah YM. Intestinal hypoxia-inducible factor-2alpha (HIF-2alpha) is critical for efficient erythropoiesis. J Biol Chem. 2011; 286(22):19533-19540. [PubMed: 21498508]

6. Anderson GJ, Frazer DM. Iron metabolism meets signal transduction. Nat Genet. 2006; 38(5):503504. [PubMed: 16642010]

7. Andrews NC. Forging a field: the golden age of iron biology. Blood. 2008; 112(2):219-230. [PubMed: 18606887]

8. Andriopoulos B Jr. Corradini E, Xia Y, Faasse SA, Chen S, Grgurevic L, Knutson MD, Pietrangelo A, Vukicevic S, Lin HY, et al. BMP6 is a key endogenous regulator of hepcidin expression and iron metabolism. Nat Genet. 2009; 41(4):482-487. [PubMed: 19252486] 
9. Ashby DR, Gale DP, Busbridge M, Murphy KG, Duncan ND, Cairns TD, Taube DH, Bloom SR, Tam FW, Chapman R, et al. Erythropoietin administration in humans causes a marked and prolonged reduction in circulating hepcidin. Haematologica. 2010; 95(3):505-508. [PubMed: 19833632]

10. Babitt JL, Huang FW, Wrighting DM, Xia Y, Sidis Y, Samad TA, Campagna JA, Chung RT, Schneyer AL, Woolf CJ, et al. Bone morphogenetic protein signaling by hemojuvelin regulates hepcidin expression. Nat Genet. 2006; 38(5):531-539. [PubMed: 16604073]

11. Babitt JL, Huang FW, Xia Y, Sidis Y, Andrews NC, Lin HY. Modulation of bone morphogenetic protein signaling in vivo regulates systemic iron balance. J Clin Invest. 2007; 117(7):1933-1939. [PubMed: 17607365]

12. Basclain KA, Shilkin KB, Withers G, Reed WD, Jeffrey GP. Cellular expression and regulation of iron transport and storage proteins in genetic haemochromatosis. Journal of gastroenterology and hepatology. 1998; 13(6):624-634. [PubMed: 9715407]

13. Beguin Y, Huebers HA, Weber G, Eng M, Finch CA. Hepatocyte iron release in rats. The Journal of laboratory and clinical medicine. 1989; 113(3):346-354. [PubMed: 2926242]

14. Benkovic SA, Connor JR. Ferritin, transferrin, and iron in selected regions of the adult and aged rat brain. The Journal of comparative neurology. 1993; 338(1):97-113. [PubMed: 8300902]

15. Bleil JD, Bretscher MS. Transferrin receptor and its recycling in HeLa cells. Embo J. 1982; 1(3): 351-355. [PubMed: 6325161]

16. Bondi A, Valentino P, Daraio F, Porporato P, Gramaglia E, Carturan S, Gottardi E, Camaschella C, Roetto A. Hepatic expression of hemochromatosis genes in two mouse strains after phlebotomy and iron overload. Haematologica. 2005; 90(9):1161-1167. [PubMed: 16154838]

17. Borgna-Pignatti C, Vergine G, Lombardo T, Cappellini MD, Cianciulli P, Maggio A, Renda D, Lai ME, Mandas A, Forni G, et al. Hepatocellular carcinoma in the thalassaemia syndromes. British journal of haematology. 2004; 124(1):114-117. [PubMed: 14675416]

18. Bozzini C, Girelli D, Olivieri O, Martinelli N, Bassi A, De Matteis G, Tenuti I, Lotto V, Friso S, Pizzolo F, et al. Prevalence of body iron excess in the metabolic syndrome. Diabetes care. 2005; 28(8):2061-2063. [PubMed: 16043762]

19. Bradbear RA, Bain C, Siskind V, Schofield FD, Webb S, Axelsen EM, Halliday JW, Bassett ML, Powell LW. Cohort study of internal malignancy in genetic hemochromatosis and other chronic nonalcoholic liver diseases. Journal of the National Cancer Institute. 1985; 75(1):81-84. [PubMed: 2989605]

20. Braliou GG, Verga Falzacappa MV, Chachami G, Casanovas G, Muckenthaler MU, Simos G. 2Oxoglutarate-dependent oxygenases control hepcidin gene expression. Journal of hepatology. 2008; 48(5):801-810. [PubMed: 18313788]

21. Brissot P, Wright TL, Ma WL, Weisiger RA. Efficient clearance of non-transferrin-bound iron by rat liver. Implications for hepatic iron loading in iron overload states. J Clin Invest. 1985; 76(4): 1463-1470. [PubMed: 4056038]

22. Bubici C, Papa S, Dean K, Franzoso G. Mutual cross-talk between reactive oxygen species and nuclear factor-kappa B: molecular basis and biological significance. Oncogene. 2006; 25(51): 6731-6748. [PubMed: 17072325]

23. Cairo G, Tacchini L, Pogliaghi G, Anzon E, Tomasi A, Bernelli-Zazzera A. Induction of ferritin synthesis by oxidative stress. Transcriptional and post-transcriptional regulation by expansion of the "free" iron pool. J Biol Chem. 1995; 270(2):700-703. [PubMed: 7822298]

24. Camaschella C, Roetto A, Cali A, De Gobbi M, Garozzo G, Carella M, Majorano N, Totaro A, Gasparini P. The gene TFR2 is mutated in a new type of haemochromatosis mapping to 7q22. Nat Genet. 2000; 25(1):14-15. [PubMed: 10802645]

25. Canonne-Hergaux F, Gruenheid S, Ponka P, Gros P. Cellular and subcellular localization of the Nramp2 iron transporter in the intestinal brush border and regulation by dietary iron. Blood. 1999; 93(12):4406-4417. [PubMed: 10361139]

26. Cartwright GE. The anemia of chronic disorders. Seminars in hematology. 1966; 3(4):351-375. [PubMed: 5341723]

27. Cartwright GE, Lauritsen MA, et al. The anemia of infection; hypoferremia, hypercupremia, and alterations in porphyrin metabolism in patients. J Clin Invest. 1946:2565-80. 
28. Cavill I. Erythropoiesis and iron. Best practice \& research. Clinical haematology. 2002; 15(2):399_ 409. [PubMed: 12401314]

29. Chaston TB, Matak P, Pourvali K, Srai SK, McKie AT, Sharp PA. Hypoxia inhibits hepcidin expression in $\mathrm{HuH} 7$ hepatoma cells via decreased SMAD4 signaling. American journal of physiology. Cell physiology. 2011; 300(4):C888-895. [PubMed: 21289291]

30. Cherukuri S, Potla R, Sarkar J, Nurko S, Harris ZL, Fox PL. Unexpected role of ceruloplasmin in intestinal iron absorption. Cell Metab. 2005; 2(5):309-319. [PubMed: 16271531]

31. Choi SO, Cho YS, Kim HL, Park JW. ROS mediate the hypoxic repression of the hepcidin gene by inhibiting C/EBPalpha and STAT-3. Biochemical and biophysical research communications. 2007; 356(1):312-317. [PubMed: 17349976]

32. Ciechanover A, Schwartz AL, Dautry-Varsat A, Lodish HF. Kinetics of internalization and recycling of transferrin and the transferrin receptor in a human hepatoma cell line. Effect of lysosomotropic agents. J Biol Chem. 1983; 258(16):9681-9689. [PubMed: 6309781]

33. Ciechanover A, Schwartz AL, Lodish HF. Sorting and recycling of cell surface receptors and endocytosed ligands: the asialoglycoprotein and transferrin receptors. Journal of cellular biochemistry. 1983; 23(1-4):107-130. [PubMed: 6327736]

34. Corradini E, Schmidt PJ, Meynard D, Garuti C, Montosi G, Chen S, Vukicevic S, Pietrangelo A, Lin HY, Babitt JL. BMP6 treatment compensates for the molecular defect and ameliorates hemochromatosis in Hfe knockout mice. Gastroenterology. 2010; 139(5):1721-1729. [PubMed: 20682319]

35. Courselaud B, Pigeon C, Inoue Y, Inoue J, Gonzalez FJ, Leroyer P, Gilot D, Boudjema K, Guguen-Guillouzo C, Brissot $\mathrm{P}$, et al. C/EBPalpha regulates hepatic transcription of hepcidin, an antimicrobial peptide and regulator of iron metabolism. Cross-talk between C/EBP pathway and iron metabolism. J Biol Chem. 2002; 277(43):41163-41170. [PubMed: 12183449]

36. Dautry-Varsat A, Ciechanover A, Lodish HF. pH and the recycling of transferrin during receptormediated endocytosis. Proc Natl Acad Sci U S A. 1983; 80(8):2258-2262. [PubMed: 6300903]

37. De Domenico I, Lo E, Ward DM, Kaplan J. Hepcidin-induced internalization of ferroportin requires binding and cooperative interaction with Jak2. Proc Natl Acad Sci U S A. 2009; 106(10): 3800-3805. [PubMed: 19234114]

38. De Domenico I, Vaughn MB, Li L, Bagley D, Musci G, Ward DM, Kaplan J. Ferroportin-mediated mobilization of ferritin iron precedes ferritin degradation by the proteasome. Embo J. 2006; 25(22):5396-5404. [PubMed: 17082767]

39. De Domenico I, Ward DM, Langelier C, Vaughn MB, Nemeth E, Sundquist WI, Ganz T, Musci G, Kaplan J. The molecular mechanism of hepcidin-mediated ferroportin down-regulation. Molecular biology of the cell. 2007; 18(7):2569-2578. [PubMed: 17475779]

40. De Domenico I, Ward DM, Musci G, Kaplan J. Evidence for the multimeric structure of ferroportin. Blood. 2007; 109(5):2205-2209. [PubMed: 17077321]

41. De Domenico I, Ward DM, Nemeth E, Vaughn MB, Musci G, Ganz T, Kaplan J. The molecular basis of ferroportin-linked hemochromatosis. Proc Natl Acad Sci U S A. 2005; 102(25):89558960. [PubMed: 15956209]

42. Dongiovanni P, Fracanzani AL, Fargion S, Valenti L. Iron in fatty liver and in the metabolic syndrome: a promising therapeutic target. Journal of hepatology. 2011; 55(4):920-932. [PubMed: 21718726]

43. Donovan A, Lima CA, Pinkus JL, Pinkus GS, Zon LI, Robine S, Andrews NC. The iron exporter ferroportin/Slc40a1 is essential for iron homeostasis. Cell Metab. 2005; 1(3):191-200. [PubMed: 16054062]

44. Du X, She E, Gelbart T, Truksa J, Lee P, Xia Y, Khovananth K, Mudd S, Mann N, Moresco EM, et al. The serine protease TMPRSS6 is required to sense iron deficiency. Science. 2008; 320(5879):1088-1092. [PubMed: 18451267]

45. Fargion S, Dongiovanni P, Guzzo A, Colombo S, Valenti L, Fracanzani AL. Iron and insulin resistance. Alimentary pharmacology \& therapeutics. 2005; 22(Suppl):261-63. [PubMed: 16091064] 
46. Feder JN, Gnirke A, Thomas W, Tsuchihashi Z, Ruddy DA, Basava A, Dormishian F, Domingo R Jr. Ellis MC, Fullan A, et al. A novel MHC class I-like gene is mutated in patients with hereditary haemochromatosis. Nat Genet. 1996; 13(4):399-408. [PubMed: 8696333]

47. Finberg KE, Heeney MM, Campagna DR, Aydinok Y, Pearson HA, Hartman KR, Mayo MM, Samuel SM, Strouse JJ, Markianos K, et al. Mutations in TMPRSS6 cause iron-refractory iron deficiency anemia (IRIDA). Nat Genet. 2008; 40(5):569-571. [PubMed: 18408718]

48. Finberg KE, Whittlesey RL, Fleming MD, Andrews NC. Down-regulation of Bmp/Smad signaling by Tmprss6 is required for maintenance of systemic iron homeostasis. Blood. 2010; 115(18): 3817-3826. [PubMed: 20200349]

49. Fleming MD, Trenor CC 3rd, Su MA, Foernzler D, Beier DR, Dietrich WF, Andrews NC. Microcytic anaemia mice have a mutation in Nramp2, a candidate iron transporter gene. Nat Genet. 1997; 16(4):383-386. [PubMed: 9241278]

50. Fleming RE, Ahmann JR, Migas MC, Waheed A, Koeffler HP, Kawabata H, Britton RS, Bacon BR, Sly WS. Targeted mutagenesis of the murine transferrin receptor-2 gene produces hemochromatosis. Proc Natl Acad Sci U S A. 2002; 99(16):10653-10658. [PubMed: 12134060]

51. Flo TH, Smith KD, Sato S, Rodriguez DJ, Holmes MA, Strong RK, Akira S, Aderem A. Lipocalin 2 mediates an innate immune response to bacterial infection by sequestrating iron. Nature. 2004; 432(7019):917-921. [PubMed: 15531878]

52. Folgueras AR, de Lara FM, Pendas AM, Garabaya C, Rodriguez F, Astudillo A, Bernal T, Cabanillas R, Lopez-Otin C, Velasco G. Membrane-bound serine protease matriptase-2 (Tmprss6) is an essential regulator of iron homeostasis. Blood. 2008; 112(6):2539-2545. [PubMed: 18523150]

53. Frazer DM, Inglis HR, Wilkins SJ, Millard KN, Steele TM, McLaren GD, McKie AT, Vulpe CD, Anderson GJ. Delayed hepcidin response explains the lag period in iron absorption following a stimulus to increase erythropoiesis. Gut. 2004; 53(10):1509-1515. [PubMed: 15361505]

54. Frazer DM, Wilkins SJ, Becker EM, Vulpe CD, McKie AT, Trinder D, Anderson GJ. Hepcidin expression inversely correlates with the expression of duodenal iron transporters and iron absorption in rats. Gastroenterology. 2002; 123(3):835-844. [PubMed: 12198710]

55. Fujita N, Takei Y. Iron overload in nonalcoholic steatohepatitis. Advances in clinical chemistry. 2011:55105-132.

56. Ganz T. Hepcidin and iron regulation, 10 years later. Blood. 2011; 117(17):4425-4433. [PubMed: 21346250]

57. Ganz T. Hepcidin, a key regulator of iron metabolism and mediator of anemia of inflammation. Blood. 2003; 102(3):783-788. [PubMed: 12663437]

58. Ganz T. Macrophages and Systemic Iron Homeostasis. Journal of innate immunity. 2012

59. Ganz T, Nemeth E. The hepcidin-ferroportin system as a therapeutic target in anemias and iron overload disorders. Hematology / the Education Program of the American Society of Hematology. American Society of Hematology. Education Program. 2011:2011538-542.

60. Gao J, Chen J, Kramer M, Tsukamoto H, Zhang AS, Enns CA. Interaction of the hereditary hemochromatosis protein HFE with transferrin receptor 2 is required for transferrin-induced hepcidin expression. Cell Metab. 2009; 9(3):217-227. [PubMed: 19254567]

61. Gardenghi S, Marongiu MF, Ramos P, Guy E, Breda L, Chadburn A, Liu Y, Amariglio N, Rechavi $\mathrm{G}$, Rachmilewitz EA, et al. Ineffective erythropoiesis in beta-thalassemia is characterized by increased iron absorption mediated by down-regulation of hepcidin and up-regulation of ferroportin. Blood. 2007; 109(11):5027-5035. [PubMed: 17299088]

62. Gardenghi S, Ramos P, Marongiu MF, Melchiori L, Breda L, Guy E, Muirhead K, Rao N, Roy $\mathrm{CN}$, Andrews NC, et al. Hepcidin as a therapeutic tool to limit iron overload and improve anemia in beta-thalassemic mice. J Clin Invest. 2010; 120(12):4466-4477. [PubMed: 21099112]

63. Gattermann N. The treatment of secondary hemochromatosis. Deutsches Arzteblatt international. 2009; 106(30):499-504. [PubMed: 19727383]

64. Goldwurm S, Casati C, Venturi N, Strada S, Santambrogio P, Indraccolo S, Arosio P, Cazzola M, Piperno A, Masera G, et al. Biochemical and genetic defects underlying human congenital hypotransferrinemia. The hematology journal : the official journal of the European Haematology Association / EHA. 2000; 1(6):390-398. [PubMed: 11920219] 
65. Gordeuk VR, Miasnikova GY, Sergueeva AI, Niu X, Nouraie M, Okhotin DJ, Polyakova LA, Ammosova T, Nekhai S, Ganz T, et al. Chuvash polycythemia VHLR200W mutation is associated with down-regulation of hepcidin expression. Blood. 2011; 118(19):5278-5282. [PubMed: 21876117]

66. Grootveld M, Bell JD, Halliwell B, Aruoma OI, Bomford A, Sadler PJ. Non-transferrin-bound iron in plasma or serum from patients with idiopathic hemochromatosis. Characterization by high performance liquid chromatography and nuclear magnetic resonance spectroscopy. J Biol Chem. 1989; 264(8):4417-4422. [PubMed: 2466835]

67. Gruenheid S, Canonne-Hergaux F, Gauthier S, Hackam DJ, Grinstein S, Gros P. The iron transport protein NRAMP2 is an integral membrane glycoprotein that colocalizes with transferrin in recycling endosomes. J Exp Med. 1999; 189(5):831-841. [PubMed: 10049947]

68. Gunshin H, Fujiwara Y, Custodio AO, Direnzo C, Robine S, Andrews NC. Slc11a2 is required for intestinal iron absorption and erythropoiesis but dispensable in placenta and liver. J Clin Invest. 2005; 115(5):1258-1266. [PubMed: 15849611]

69. Gunshin H, Mackenzie B, Berger UV, Gunshin Y, Romero MF, Boron WF, Nussberger S, Gollan JL, Hediger MA. Cloning and characterization of a mammalian proton-coupled metal-ion transporter. Nature. 1997; 388(6641):482-488. [PubMed: 9242408]

70. Hahn P, Qian Y, Dentchev T, Chen L, Beard J, Harris ZL, Dunaief JL. Disruption of ceruloplasmin and hephaestin in mice causes retinal iron overload and retinal degeneration with features of agerelated macular degeneration. Proc Natl Acad Sci U S A. 2004; 101(38):13850-13855. [PubMed: 15365174]

71. Hann HW, Stahlhut MW, Blumberg BS. Iron nutrition and tumor growth: decreased tumor growth in iron-deficient mice. Cancer research. 1988; 48(15):4168-4170. [PubMed: 3390810]

72. Harding C, Stahl P. Transferrin recycling in reticulocytes: $\mathrm{pH}$ and iron are important determinants of ligand binding and processing. Biochemical and biophysical research communications. 1983; 113(2):650-658. [PubMed: 6870878]

73. Harris ZL, Takahashi Y, Miyajima H, Serizawa M, MacGillivray RT, Gitlin JD. Aceruloplasminemia: molecular characterization of this disorder of iron metabolism. Proc Natl Acad Sci U S A. 1995; 92(7):2539-2543. [PubMed: 7708681]

74. Hattori A, Tomosugi N, Tatsumi Y, Suzuki A, Hayashi K, Katano Y, Inagaki Y, Ishikawa T, Hayashi $\mathrm{H}$, Goto $\mathrm{H}$, et al. Identification of a novel mutation in the HAMP gene that causes nondetectable hepcidin molecules in a Japanese male patient with juvenile hemochromatosis. Blood cells, molecules \& diseases. 2012; 48(3):179-182.

75. Hayashi A, Wada Y, Suzuki T, Shimizu A. Studies on familial hypotransferrinemia: unique clinical course and molecular pathology. American journal of human genetics. 1993; 53(1):201213. [PubMed: 8317485]

76. Heinrich HC, Gabbe EE, Oppitz KH, Whang DH, Bender-Gotze C, Schafer KH, Schroter W, Pfau AA. Absorption of inorganic and food iron in children with heterozygous and homozygous betathalassemia. Z Kinderheilkd. 1973; 115(1):1-22. [PubMed: 4796508]

77. Hentze MW, Kuhn LC. Molecular control of vertebrate iron metabolism: mRNA-based regulatory circuits operated by iron, nitric oxide, and oxidative stress. Proc Natl Acad Sci U S A. 1996; 93(16):8175-8182. [PubMed: 8710843]

78. Hvidberg V, Maniecki MB, Jacobsen C, Hojrup P, Moller HJ, Moestrup SK. Identification of the receptor scavenging hemopexin-heme complexes. Blood. 2005; 106(7):2572-2579. [PubMed: 15947085]

79. Hwang PK, Greer J. Interaction between hemoglobin subunits in the hemoglobin . haptoglobin complex. J Biol Chem. 1980; 255(7):3038-3041. [PubMed: 7358726]

80. Iolascon A, Camaschella C, Pospisilova D, Piscopo C, Tchernia G, Beaumont C. Natural history of recessive inheritance of DMT1 mutations. The Journal of pediatrics. 2008; 152(1):136-139.

[PubMed: 18154916]

81. Isom HC, McDevitt EI, Moon MS. Elevated hepatic iron: a confounding factor in chronic hepatitis C. Biochimica et biophysica acta. 2009; 1790(7):650-662. [PubMed: 19393721] 
82. Kanda J, Mizumoto C, Kawabata H, Tsuchida H, Tomosugi N, Matsuo K, Uchiyama T. Serum hepcidin level and erythropoietic activity after hematopoietic stem cell transplantation. Haematologica. 2008; 93(10):1550-1554. [PubMed: 18641032]

83. Kaplan J. Mechanisms of cellular iron acquisition: another iron in the fire. Cell. 2002; 111(5):603606. [PubMed: 12464171]

84. Kaplan J, Ward DM, De Domenico I. The molecular basis of iron overload disorders and ironlinked anemias. International journal of hematology. 2011; 93(1):14-20. [PubMed: 21210258]

85. Kautz L, Meynard D, Monnier A, Darnaud V, Bouvet R, Wang RH, Deng C, Vaulont S, Mosser J, Coppin H, et al. Iron regulates phosphorylation of Smad1/5/8 and gene expression of Bmp6, Smad7, Id1, and Atoh8 in the mouse liver. Blood. 2008; 112(4):1503-1509. [PubMed: 18539898]

86. Kawabata H, Fleming RE, Gui D, Moon SY, Saitoh T, O'Kelly J, Umehara Y, Wano Y, Said JW, Koeffler HP. Expression of hepcidin is down-regulated in TfR2 mutant mice manifesting a phenotype of hereditary hemochromatosis. Blood. 2005; 105(1):376-381. [PubMed: 15345587]

87. Kawabata H, Nakamaki T, Ikonomi P, Smith RD, Germain RS, Koeffler HP. Expression of transferrin receptor 2 in normal and neoplastic hematopoietic cells. Blood. 2001; 98(9):27142719. [PubMed: 11675342]

88. Kemna E, Pickkers P, Nemeth E, van der Hoeven H, Swinkels D. Time-course analysis of hepcidin, serum iron, and plasma cytokine levels in humans injected with LPS. Blood. 2005; 106(5):1864-1866. [PubMed: 15886319]

89. Knutson MD, Oukka M, Koss LM, Aydemir F, Wessling-Resnick M. Iron release from macrophages after erythrophagocytosis is up-regulated by ferroportin 1 overexpression and downregulated by hepcidin. Proc Natl Acad Sci U S A. 2005; 102(5):1324-1328. [PubMed: 15665091]

90. Koppenol WH. The Haber-Weiss cycle--70 years later. Redox report : communications in free radical research. 2001; 6(4):229-234. [PubMed: 11642713]

91. Krause A, Neitz S, Magert HJ, Schulz A, Forssmann WG, Schulz-Knappe P, Adermann K. LEAP-1, a novel highly disulfide-bonded human peptide, exhibits antimicrobial activity. FEBS letters. 2000; 480(2-3):147-150. [PubMed: 11034317]

92. Kristiansen M, Graversen JH, Jacobsen C, Sonne O, Hoffman HJ, Law SK, Moestrup SK. Identification of the haemoglobin scavenger receptor. Nature. 2001; 409(6817):198-201. [PubMed: 11196644]

93. Kwiatkowski JL. Real-world use of iron chelators. Hematology / the Education Program of the American Society of Hematology. American Society of Hematology. Education Program. 2011:2011451-458.

94. Lakhal S, Schodel J, Townsend AR, Pugh CW, Ratcliffe PJ, Mole DR. Regulation of type II transmembrane serine proteinase TMPRSS6 by hypoxia-inducible factors: new link between hypoxia signaling and iron homeostasis. J Biol Chem. 2011; 286(6):4090-4097. [PubMed: 20966077]

95. Lamb JE, Ray F, Ward JH, Kushner JP, Kaplan J. Internalization and subcellular localization of transferrin and transferrin receptors in HeLa cells. J Biol Chem. 1983; 258(14):8751-8758. [PubMed: 6305999]

96. Lambert LA. Molecular evolution of the transferrin family and associated receptors. Biochimica et biophysica acta. 2012; 1820(3):244-255. [PubMed: 21693173]

97. Lambert LA, Perri H, Halbrooks PJ, Mason AB. Evolution of the transferrin family: conservation of residues associated with iron and anion binding. Comparative biochemistry and physiology. Part B, Biochemistry \& molecular biology. 2005; 142(2):129-141.

98. Lambert LA, Perri H, Meehan TJ. Evolution of duplications in the transferrin family of proteins. Comparative biochemistry and physiology. Part B, Biochemistry \& molecular biology. 2005; 140(1):11-25.

99. Lasocki S, Millot S, Andrieu V, Letteron P, Pilard N, Muzeau F, Thibaudeau O, Montravers P, Beaumont C. Phlebotomies or erythropoietin injections allow mobilization of iron stores in a mouse model mimicking intensive care anemia. Critical care medicine. 2008; 36(8):2388-2394. [PubMed: 18664788]

100. Latunde-Dada GO, Simpson RJ, McKie AT. Duodenal cytochrome B expression stimulates iron uptake by human intestinal epithelial cells. J Nutr. 2008; 138(6):991-995. [PubMed: 18492824] 
101. Lesbordes-Brion JC, Viatte L, Bennoun M, Lou DQ, Ramey G, Houbron C, Hamard G, Kahn A, Vaulont S. Targeted disruption of the hepcidin 1 gene results in severe hemochromatosis. Blood. 2006; 108(4):1402-1405. [PubMed: 16574947]

102. Levy JE, Montross LK, Cohen DE, Fleming MD, Andrews NC. The C282Y mutation causing hereditary hemochromatosis does not produce a null allele. Blood. 1999; 94(1):9-11. [PubMed: 10381492]

103. Li JY, Paragas N, Ned RM, Qiu A, Viltard M, Leete T, Drexler IR, Chen X, Sanna-Cherchi S, Mohammed F, et al. Scara5 is a ferritin receptor mediating non-transferrin iron delivery. Developmental cell. 2009; 16(1):35-46. [PubMed: 19154717]

104. Lillie RD. Experiments on the solubility of hemosiderin in acids and other reagents during and after various fixations. Am J Pathol. 1939; 15(2):225-239. [PubMed: 19970443]

105. Liuzzi JP, Aydemir F, Nam H, Knutson MD, Cousins RJ. Zip14 (Slc39a14) mediates nontransferrin-bound iron uptake into cells. Proc Natl Acad Sci U S A. 2006; 103(37):13612-13617. [PubMed: 16950869]

106. Lundvall O, Weinfeld A, Lundin P. Iron stores in alcohol abusers. I. Liver iron. Acta medica Scandinavica. 1969; 185(4):259-269. [PubMed: 5806335]

107. Mackenzie B, Garrick MD. Iron Imports. II. Iron uptake at the apical membrane in the intestine. Am J Physiol Gastrointest Liver Physiol. 2005; 289(6):G981-986. [PubMed: 16286504]

108. Mastrogiannaki M, Matak P, Mathieu JR, Delga S, Mayeux P, Vaulont S, Peyssonnaux C. Hepatic HIF-2 down-regulates hepcidin expression in mice through epo-mediated increase in erythropoiesis. Haematologica. 2011

109. McKie AT, Barrow D, Latunde-Dada GO, Rolfs A, Sager G, Mudaly E, Mudaly M, Richardson C, Barlow D, Bomford A, et al. An iron-regulated ferric reductase associated with the absorption of dietary iron. Science. 2001; 291(5509):1755-1759. [PubMed: 11230685]

110. McKie AT, Marciani P, Rolfs A, Brennan K, Wehr K, Barrow D, Miret S, Bomford A, Peters TJ, Farzaneh F, et al. A novel duodenal iron-regulated transporter, IREG1, implicated in the basolateral transfer of iron to the circulation. Mol Cell. 2000; 5(2):299-309. [PubMed: 10882071]

111. Meynard D, Kautz L, Darnaud V, Canonne-Hergaux F, Coppin H, Roth MP. Lack of the bone morphogenetic protein BMP6 induces massive iron overload. Nat Genet. 2009; 41(4):478-481. [PubMed: 19252488]

112. Morgan MJ, Liu ZG. Crosstalk of reactive oxygen species and NF-kappaB signaling. Cell Res. 2011; 21(1):103-115. [PubMed: 21187859]

113. Muckenthaler MU, Galy B, Hentze MW. Systemic iron homeostasis and the iron-responsive element/iron-regulatory protein (IRE/IRP) regulatory network. Annual review of nutrition. 2008:28197-213.

114. Nemeth E, Ganz T. The role of hepcidin in iron metabolism. Acta Haematol. 2009; 122(2-3):7886. [PubMed: 19907144]

115. Nemeth E, Rivera S, Gabayan V, Keller C, Taudorf S, Pedersen BK, Ganz T. IL-6 mediates hypoferremia of inflammation by inducing the synthesis of the iron regulatory hormone hepcidin. J Clin Invest. 2004; 113(9):1271-1276. [PubMed: 15124018]

116. Nemeth E, Roetto A, Garozzo G, Ganz T, Camaschella C. Hepcidin is decreased in TFR2 hemochromatosis. Blood. 2005; 105(4):1803-1806. [PubMed: 15486069]

117. Nemeth E, Tuttle MS, Powelson J, Vaughn MB, Donovan A, Ward DM, Ganz T, Kaplan J. Hepcidin regulates cellular iron efflux by binding to ferroportin and inducing its internalization. Science. 2004; 306(5704):2090-2093. [PubMed: 15514116]

118. Nemeth E, Valore EV, Territo M, Schiller G, Lichtenstein A, Ganz T. Hepcidin, a putative mediator of anemia of inflammation, is a type II acute-phase protein. Blood. 2003; 101(7):24612463. [PubMed: 12433676]

119. Nicolas G, Bennoun M, Devaux I, Beaumont C, Grandchamp B, Kahn A, Vaulont S. Lack of hepcidin gene expression and severe tissue iron overload in upstream stimulatory factor 2 (USF2) knockout mice. Proc Natl Acad Sci U S A. 2001; 98(15):8780-8785. [PubMed: 11447267] 
120. Nicolas G, Bennoun M, Porteu A, Mativet S, Beaumont C, Grandchamp B, Sirito M, Sawadogo M, Kahn A, Vaulont S. Severe iron deficiency anemia in transgenic mice expressing liver hepcidin. Proc Natl Acad Sci U S A. 2002; 99(7):4596-4601. [PubMed: 11930010]

121. Nicolas G, Chauvet C, Viatte L, Danan JL, Bigard X, Devaux I, Beaumont C, Kahn A, Vaulont S. The gene encoding the iron regulatory peptide hepcidin is regulated by anemia, hypoxia, and inflammation. J Clin Invest. 2002; 110(7):1037-1044. [PubMed: 12370282]

122. Nicolas G, Viatte L, Lou DQ, Bennoun M, Beaumont C, Kahn A, Andrews NC, Vaulont S. Constitutive hepcidin expression prevents iron overload in a mouse model of hemochromatosis. Nat Genet. 2003; 34(1):97-101. [PubMed: 12704388]

123. Niederau C, Fischer R, Purschel A, Stremmel W, Haussinger D, Strohmeyer G. Long-term survival in patients with hereditary hemochromatosis. Gastroenterology. 1996; 110(4):11071119. [PubMed: 8613000]

124. Niederau C, Fischer R, Sonnenberg A, Stremmel W, Trampisch HJ, Strohmeyer G. Survival and causes of death in cirrhotic and in noncirrhotic patients with primary hemochromatosis. The New England journal of medicine. 1985; 313(20):1256-1262. [PubMed: 4058506]

125. Niederkofler V, Salie R, Arber S. Hemojuvelin is essential for dietary iron sensing, and its mutation leads to severe iron overload. J Clin Invest. 2005; 115(8):2180-2186. [PubMed: 16075058]

126. Ohgami RS, Campagna DR, Greer EL, Antiochos B, McDonald A, Chen J, Sharp JJ, Fujiwara Y, Barker JE, Fleming MD. Identification of a ferrireductase required for efficient transferrindependent iron uptake in erythroid cells. Nat Genet. 2005; 37(11):1264-1269. [PubMed: 16227996]

127. Ohgami RS, Campagna DR, McDonald A, Fleming MD. The Steap proteins are metalloreductases. Blood. 2006; 108(4):1388-1394. [PubMed: 16609065]

128. Olynyk JK, Cullen DJ, Aquilia S, Rossi E, Summerville L, Powell LW. A population-based study of the clinical expression of the hemochromatosis gene. The New England journal of medicine. 1999; 341(10):718-724. [PubMed: 10471457]

129. Osaki S, Johnson DA. Mobilization of liver iron by ferroxidase (ceruloplasmin). J Biol Chem. 1969; 244(20):5757-5758. [PubMed: 5360468]

130. Osaki S, Johnson DA, Frieden E. The possible significance of the ferrous oxidase activity of ceruloplasmin in normal human serum. J Biol Chem. 1966; 241(12):2746-2751. [PubMed: 5912351]

131. Oudit GY, Sun H, Trivieri MG, Koch SE, Dawood F, Ackerley C, Yazdanpanah M, Wilson GJ, Schwartz A, Liu PP, et al. L-type Ca2+ channels provide a major pathway for iron entry into cardiomyocytes in iron-overload cardiomyopathy. Nature medicine. 2003; 9(9):1187-1194.

132. Papanikolaou G, Samuels ME, Ludwig EH, MacDonald ML, Franchini PL, Dube MP, Andres L, MacFarlane J, Sakellaropoulos N, Politou M, et al. Mutations in HFE2 cause iron overload in chromosome 1q-linked juvenile hemochromatosis. Nat Genet. 2004; 36(1):77-82. [PubMed: 14647275]

133. Parrow NL, Gardenghi S, Ramos P, Casu C, Grady RW, Anderson ER, Shah YM, Li H, Ginzburg YZ, Fleming RE, et al. Decreased hepcidin expression in murine beta-thalassemia is associated with suppression of Bmp/Smad signaling. Blood. 2012; 119(13):3187-3189. [PubMed: 22461476]

134. Peyssonnaux C, Zinkernagel AS, Schuepbach RA, Rankin E, Vaulont S, Haase VH, Nizet V, Johnson RS. Regulation of iron homeostasis by the hypoxia-inducible transcription factors (HIFs). J Clin Invest. 2007; 117(7):1926-1932. [PubMed: 17557118]

135. Pietrangelo A, Gualdi R, Casalgrandi G, Geerts A, De Bleser P, Montosi G, Ventura E. Enhanced hepatic collagen type I mRNA expression into fat-storing cells in a rodent model of hemochromatosis. Hepatology. 1994; 19(3):714-721. [PubMed: 8119698]

136. Pigeon C, Ilyin G, Courselaud B, Leroyer P, Turlin B, Brissot P, Loreal O. A new mouse liverspecific gene, encoding a protein homologous to human antimicrobial peptide hepcidin, is overexpressed during iron overload. J Biol Chem. 2001; 276(11):7811-7819. [PubMed: 11113132] 
137. Pinto JP, Ribeiro S, Pontes H, Thowfeequ S, Tosh D, Carvalho F, Porto G. Erythropoietin mediates hepcidin expression in hepatocytes through EPOR signaling and regulation of $\mathrm{C} /$ EBPalpha. Blood. 2008; 111(12):5727-5733. [PubMed: 18326822]

138. Ponka $P$, Beaumont $C$, Richardson DR. Function and regulation of transferrin and ferritin. Seminars in hematology. 1998; 35(1):35-54. [PubMed: 9460808]

139. Powell LW. Normal human iron storage and its relation to ethanol consumption. Australasian annals of medicine. 1966; 15(2):110-115. [PubMed: 5924570]

140. Preza GC, Ruchala P, Pinon R, Ramos E, Qiao B, Peralta MA, Sharma S, Waring A, Ganz T, Nemeth E. Minihepcidins are rationally designed small peptides that mimic hepcidin activity in mice and may be useful for the treatment of iron overload. J Clin Invest. 2011; 121(12):48804888. [PubMed: 22045566]

141. Qiao B, Sugianto P, Fung E, Del-Castillo-Rueda A, Moran-Jimenez MJ, Ganz T, Nemeth E. Hepcidin-induced endocytosis of ferroportin is dependent on ferroportin ubiquitination. Cell Metab. 2012; 15(6):918-924. [PubMed: 22682227]

142. Radisky DC, Kaplan J. Iron in cytosolic ferritin can be recycled through lysosomal degradation in human fibroblasts. Biochem J. 1998; 336(Pt 1):201-205. [PubMed: 9806901]

143. Rajpathak SN, Crandall JP, Wylie-Rosett J, Kabat GC, Rohan TE, Hu FB. The role of iron in type 2 diabetes in humans. Biochimica et biophysica acta. 2009; 1790(7):671-681. [PubMed: 18501198]

144. Ramey G, Deschemin JC, Durel B, Canonne-Hergaux F, Nicolas G, Vaulont S. Hepcidin targets ferroportin for degradation in hepatocytes. Haematologica. 2010; 95(3):501-504. [PubMed: 19773263]

145. Ramm GA, Ruddell RG. Hepatotoxicity of iron overload: mechanisms of iron-induced hepatic fibrogenesis. Seminars in liver disease. 2005; 25(4):433-449. [PubMed: 16315137]

146. Remacle J, Raes M, Toussaint O, Renard P, Rao G. Low levels of reactive oxygen species as modulators of cell function. Mutat Res. 1995; 316(3):103-122. [PubMed: 7862174]

147. Rivera S, Ganz T. Animal models of anemia of inflammation. Seminars in hematology. 2009; 46(4):351-357. [PubMed: 19786203]

148. Ross SL, Tran L, Winters A, Lee KJ, Plewa C, Foltz I, King C, Miranda LP, Allen J, Beckman H, et al. Molecular Mechanism of Hepcidin-Mediated Ferroportin Internalization Requires Ferroportin Lysines, Not Tyrosines or JAK-STAT. Cell Metab. 2012; 15(6):905-917. [PubMed: 22682226]

149. Rous P. Urinary Siderosis : Hemosiderin Granules in the Urine as an Aid in the Diagnosis of Pernicious Anemia, Hemochromatosis, and Other Diseases Causing Siderosis of the Kidney. J Exp Med. 1918; 28(5):645-658. [PubMed: 19868284]

150. Roy CN, Custodio AO, de Graaf J, Schneider S, Akpan I, Montross LK, Sanchez M, Gaudino A, Hentze MW, Andrews NC, et al. An Hfe-dependent pathway mediates hyposideremia in response to lipopolysaccharide-induced inflammation in mice. Nat Genet. 2004; 36(5):481-485. [PubMed: 15098034]

151. Sakaida I, Hironaka K, Uchida K, Okita K. Iron chelator deferoxamine reduces preneoplastic lesions in liver induced by choline-deficient L-amino acid-defined diet in rats. Digestive diseases and sciences. 1999; 44(3):560-569. [PubMed: 10080151]

152. Santos PC, Krieger JE, Pereira AC. Molecular diagnostic and pathogenesis of hereditary hemochromatosis. International journal of molecular sciences. 2012; 13(2):1497-1511. [PubMed: 22408404]

153. Schmidt PJ, Toran PT, Giannetti AM, Bjorkman PJ, Andrews NC. The transferrin receptor modulates Hfe-dependent regulation of hepcidin expression. Cell Metab. 2008; 7(3):205-214. [PubMed: 18316026]

154. Shindo M, Torimoto Y, Saito H, Motomura W, Ikuta K, Sato K, Fujimoto Y, Kohgo Y. Functional role of DMT1 in transferrin-independent iron uptake by human hepatocyte and hepatocellular carcinoma cell, HLF. Hepatology research : the official journal of the Japan Society of Hepatology. 2006; 35(3):152-162. [PubMed: 16707273] 
155. Silvestri L, Pagani A, Nai A, De Domenico I, Kaplan J, Camaschella C. The serine protease matriptase-2 (TMPRSS6) inhibits hepcidin activation by cleaving membrane hemojuvelin. Cell Metab. 2008; 8(6):502-511. [PubMed: 18976966]

156. Skillings JR, Rogers-Melamed I, Nabholtz JM, Sawka C, Gwadry-Sridhar F, Moquin JP, Rubinger M, Ganguly P, Burnell M, Shustik C, et al. An epidemiological review of red cell transfusions in cancer chemotherapy. Cancer prevention \& control : CPC $=$ Prevention \& controle en cancerologie : PCC. 1999; 3(3):207-212. [PubMed: 10474769]

157. Skinner MK, Griswold MD. Secretion of testicular transferrin by cultured Sertoli cells is regulated by hormones and retinoids. Biology of reproduction. 1982; 27(1):211-221. [PubMed: 6810965]

158. Song SN, Tomosugi N, Kawabata H, Ishikawa T, Nishikawa T, Yoshizaki K. Down-regulation of hepcidin resulting from long-term treatment with an anti-IL-6 receptor antibody (tocilizumab) improves anemia of inflammation in multicentric Castleman disease. Blood. 2010; 116(18): 3627-3634. [PubMed: 20644113]

159. Sposi NM, Cianetti L, Tritarelli E, Pelosi E, Militi S, Barberi T, Gabbianelli M, Saulle E, Kuhn L, Peschle C, et al. Mechanisms of differential transferrin receptor expression in normal hematopoiesis. European journal of biochemistry / FEBS. 2000; 267(23):6762-6774. [PubMed: 11082186]

160. Stal P, Broome U, Scheynius A, Befrits R, Hultcrantz R. Kupffer cell iron overload induces intercellular adhesion molecule-1 expression on hepatocytes in genetic hemochromatosis. Hepatology. 1995; 21(5):1308-1316. [PubMed: 7737636]

161. Steinberg MH, FB.; Higgs, DR.; Nagel, RL. Disorders of hemoglobin: Geetics, Pathophysiology and Clincal Management. Cambridge University Press; Cambridge, United Kingdom: 2001.

162. Strohmeyer G, Niederau C, Stremmel W. Survival and causes of death in hemochromatosis. Observations in 163 patients. Annals of the New York Academy of Sciences. 1988:526245-257.

163. Sun CC, Vaja V, Babitt JL, Lin HY. Targeting the hepcidin-ferroportin axis to develop new treatment strategies for anemia of chronic disease and anemia of inflammation. American journal of hematology. 2012; 87(4):392-400. [PubMed: 22290531]

164. Taher A, Hershko C, Cappellini MD. Iron overload in thalassaemia intermedia: reassessment of iron chelation strategies. Br J Haematol. 2009; 147(5):634-640. [PubMed: 19681884]

165. Tanno T, Bhanu NV, Oneal PA, Goh SH, Staker P, Lee YT, Moroney JW, Reed CH, Luban NL, Wang RH, et al. High levels of GDF15 in thalassemia suppress expression of the iron regulatory protein hepcidin. Nature medicine. 2007; 13(9):1096-1101.

166. Tanno T, Porayette P, Sripichai O, Noh SJ, Byrnes C, Bhupatiraju A, Lee YT, Goodnough JB, Harandi O, Ganz T, et al. Identification of TWSG1 as a second novel erythroid regulator of hepcidin expression in murine and human cells. Blood. 2009; 114(1):181-186. [PubMed: 19414861]

167. Theil EC. Ferritin: structure, gene regulation, and cellular function in animals, plants, and microorganisms. Annual review of biochemistry. 1987:56289-315.

168. Tolosano E, Altruda F. Hemopexin: structure, function, and regulation. DNA and cell biology. 2002; 21(4):297-306. [PubMed: 12042069]

169. Torti SV, Kwak EL, Miller SC, Miller LL, Ringold GM, Myambo KB, Young AP, Torti FM. The molecular cloning and characterization of murine ferritin heavy chain, a tumor necrosis factorinducible gene. J Biol Chem. 1988; 263(25):12638-12644. [PubMed: 3410854]

170. Toth I, Yuan L, Rogers JT, Boyce H, Bridges KR. Hypoxia alters iron-regulatory protein-1 binding capacity and modulates cellular iron homeostasis in human hepatoma and erythroleukemia cells. J Biol Chem. 1999; 274(7):4467-4473. [PubMed: 9933651]

171. Trenor CC 3rd, Campagna DR, Sellers VM, Andrews NC, Fleming MD. The molecular defect in hypotransferrinemic mice. Blood. 2000; 96(3):1113-1118. [PubMed: 10910930]

172. Trombini P, Paolini V, Pelucchi S, Mariani R, Nemeth E, Ganz T, Piperno A. Hepcidin response to acute iron intake and chronic iron loading in dysmetabolic iron overload syndrome. Liver Int. 2011; 31(7):994-1000. [PubMed: 21733088] 
173. Tsuji Y, Ayaki H, Whitman SP, Morrow CS, Torti SV, Torti FM. Coordinate transcriptional and translational regulation of ferritin in response to oxidative stress. Molecular and cellular biology. 2000; 20(16):5818-5827. [PubMed: 10913165]

174. Valenti L, Dongiovanni P, Fracanzani AL, Santorelli G, Fatta E, Bertelli C, Taioli E, Fiorelli G, Fargion S. Increased susceptibility to nonalcoholic fatty liver disease in heterozygotes for the mutation responsible for hereditary hemochromatosis. Digestive and liver disease : official journal of the Italian Society of Gastroenterology and the Italian Association for the Study of the Liver. 2003; 35(3):172-178. [PubMed: 12779071]

175. Valore EV, Ganz T. Posttranslational processing of hepcidin in human hepatocytes is mediated by the prohormone convertase furin. Blood cells, molecules \& diseases. 2008; 40(1):132-138.

176. Verga Falzacappa MV, Vujic Spasic M, Kessler R, Stolte J, Hentze MW, Muckenthaler MU. STAT3 mediates hepatic hepcidin expression and its inflammatory stimulation. Blood. 2007; 109(1):353-358. [PubMed: 16946298]

177. Viatte L, Nicolas G, Lou DQ, Bennoun M, Lesbordes-Brion JC, Canonne- Hergaux F, Schonig K, Bujard H, Kahn A, Andrews NC, et al. Chronic hepcidin induction causes hyposideremia and alters the pattern of cellular iron accumulation in hemochromatotic mice. Blood. 2006; 107(7): 2952-2958. [PubMed: 16339398]

178. Vokurka M, Krijt J, Sulc K, Necas E. Hepcidin mRNA levels in mouse liver respond to inhibition of erythropoiesis. Physiological research / Academia Scientiarum Bohemoslovaca. 2006; 55(6): 667-674. [PubMed: 16497104]

179. Volke M, Gale DP, Maegdefrau U, Schley G, Klanke B, Bosserhoff AK, Maxwell PH, Eckardt $\mathrm{KU}$, Warnecke C. Evidence for a lack of a direct transcriptional suppression of the iron regulatory peptide hepcidin by hypoxiainducible factors. PLoS One. 2009; 4(11):e7875. [PubMed: 19924283]

180. Vujic Spasic M, Kiss J, Herrmann T, Galy B, Martinache S, Stolte J, Grone HJ, Stremmel W, Hentze MW, Muckenthaler MU. Hfe acts in hepatocytes to prevent hemochromatosis. Cell Metab. 2008; 7(2):173-178. [PubMed: 18249176]

181. Vujic Spasic M, Kiss J, Herrmann T, Kessler R, Stolte J, Galy B, Rathkolb B, Wolf E, Stremmel W, Hentze MW, et al. Physiologic systemic iron metabolism in mice deficient for duodenal Hfe. Blood. 2007; 109(10):4511-4517. [PubMed: 17264297]

182. Wallace DF, Summerville L, Subramaniam VN. Targeted disruption of the hepatic transferrin receptor 2 gene in mice leads to iron overload. Gastroenterology. 2007; 132(1):301-310. [PubMed: 17241880]

183. Wang RH, Li C, Xu X, Zheng Y, Xiao C, Zerfas P, Cooperman S, Eckhaus M, Rouault T, Mishra $\mathrm{L}$, et al. A role of SMAD4 in iron metabolism through the positive regulation of hepcidin expression. Cell Metab. 2005; 2(6):399-409. [PubMed: 16330325]

184. Wei Y, Miller SC, Tsuji Y, Torti SV, Torti FM. Interleukin 1 induces ferritin heavy chain in human muscle cells. Biochemical and biophysical research communications. 1990; 169(1):289296. [PubMed: 2350350]

185. Wrighting DM, Andrews NC. Interleukin-6 induces hepcidin expression through STAT3. Blood. 2006; 108(9):3204-3209. [PubMed: 16835372]

186. Yang B, Kirby S, Lewis J, Detloff PJ, Maeda N, Smithies O. A mouse model for beta 0thalassemia. Proc Natl Acad Sci U S A. 1995; 92(25):11608-11612. [PubMed: 8524813]

187. Yoshida K, Furihata K, Takeda S, Nakamura A, Yamamoto K, Morita H, Hiyamuta S, Ikeda S, Shimizu N, Yanagisawa N. A mutation in the ceruloplasmin gene is associated with systemic hemosiderosis in humans. Nat Genet. 1995; 9(3):267-272. [PubMed: 7539672]

188. Zhang AS, Gao J, Koeberl DD, Enns CA. The role of hepatocyte hemojuvelin in the regulation of bone morphogenic protein-6 and hepcidin expression in vivo. J Biol Chem. 2010; 285(22): 16416-16423. [PubMed: 20363739]

189. Zhang Z, Zhang F, An P, Guo X, Shen Y, Tao Y, Wu Q, Zhang Y, Yu Y, Ning B, et al. Ferroportin1 deficiency in mouse macrophages impairs iron homeostasis and inflammatory responses. Blood. 2011; 118(7):1912-1922. [PubMed: 21705499]

190. Zhang Z, Zhang F, Guo X, An P, Tao Y, Wang F. Ferroportin1 in hepatocytes and macrophages is required for the efficient mobilization of body iron stores. Hepatology. 2012 
191. Zhao N, Gao J, Enns CA, Knutson MD. ZRT/IRT-like protein 14 (ZIP14) promotes the cellular assimilation of iron from transferrin. J Biol Chem. 2010; 285(42):32141-32150. [PubMed: 20682781] 


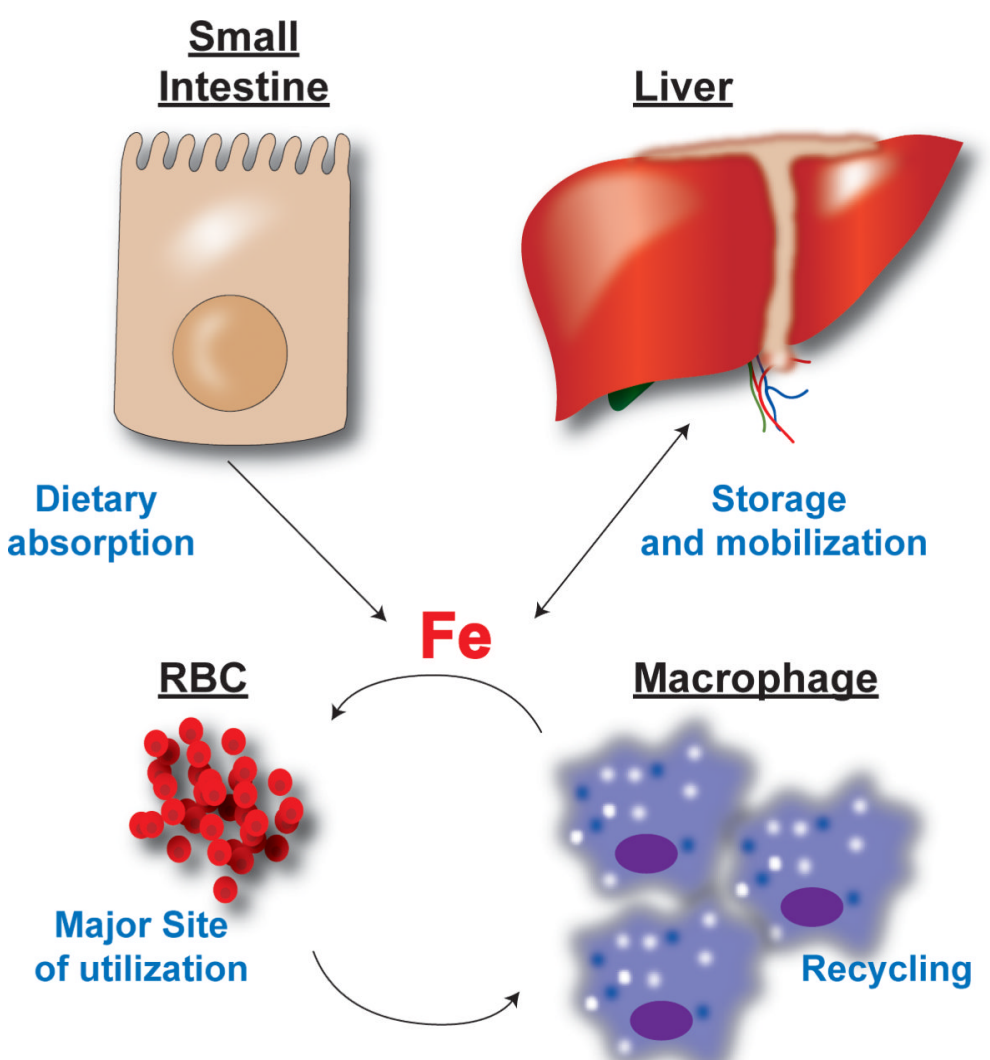

Figure 1. Systemic iron regulation

Dietary iron is absorbed through the small intestine and mainly utilized for RBC production. Hepatic and splenic macrophages recycle iron from senescent RBCs. The iron derived from recycling is used for production of RBCs. During times of iron excess the liver can store iron and during increased systemic needs the liver can mobilize iron stores for utilization. 

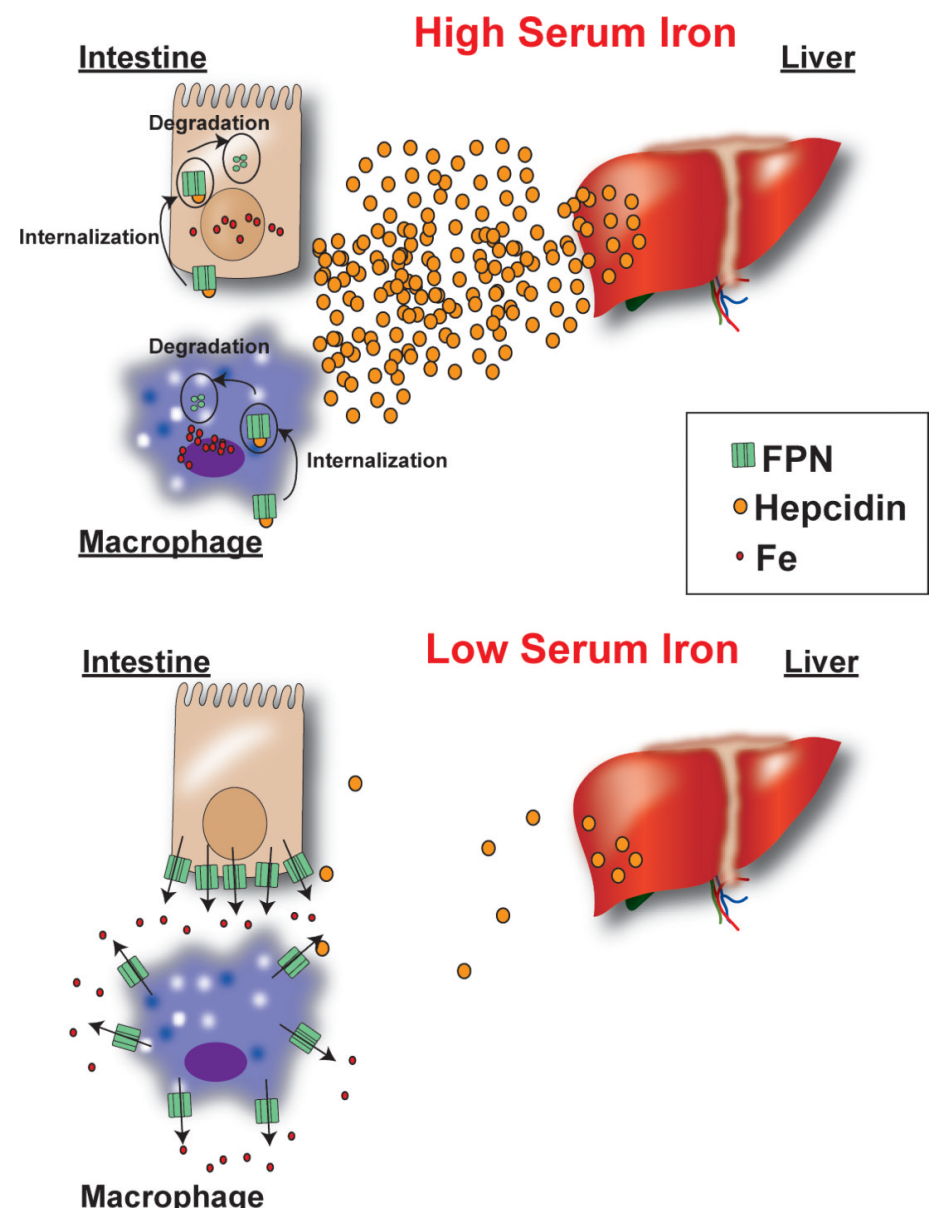

\section{Low Serum Iron Liver}

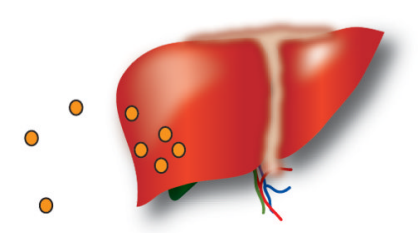

$\circ$

Figure 2. Hepcidin regulation of FPN protein expression during changes in systemic iron levels High iron levels increase hepcidin expression, which decrease iron export from the small intestine and macrophage due to an internalization and degradation of FPN. Iron deficiency results in a decrease in hepcidin levels and stabilization of FPN protein expression. 


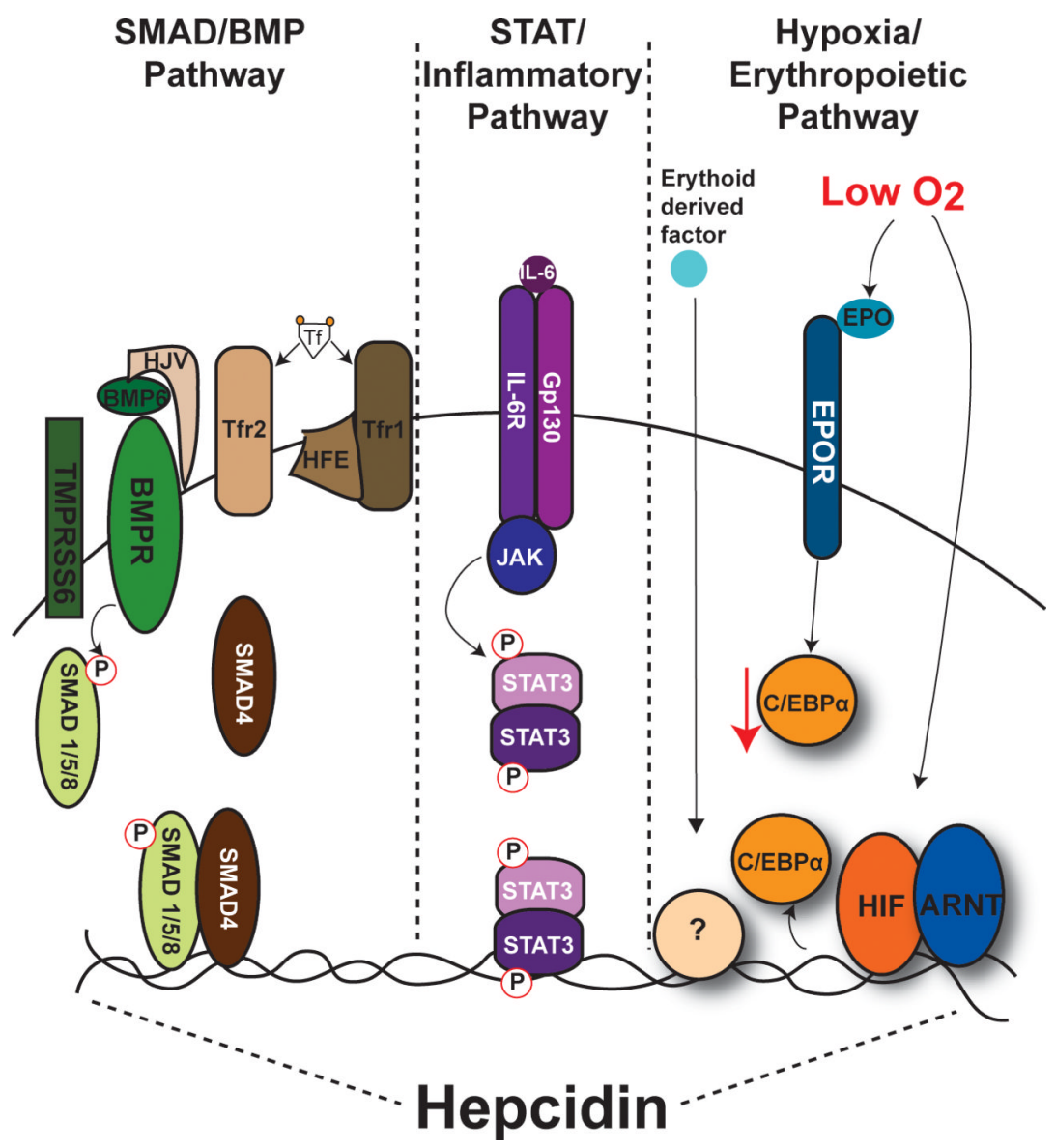

Figure 3. Regulation of hepcidin by BMP/SMAD, inflammatory and hypoxia/erythropoietic signaling in the liver

Three major pathways are critical for regulating basal and stimuli-induced hepcidin expression. Binding of iron containing Tf to Tfr1 causes a dissociation of Tfr1-High FE (HFE) complex and an interaction of HFE with Tfr2. Increased stabilization of Tfr2 increases BMP6 mediated phosphorylation of SMAD1/5/ 8 and recruitment of SMAD 1/5/8 and SMAD4 to the hepcidin proximal promoter. BMP/SMAD signaling is the major pathway by which hepcidin expression is coordinated to meet systemic iron requirements. Activation of hepcidin by inflammation is thought to act independently of the BMP/SMAD pathway. The best-studied mechanism is via the pro-inflammatory mediator IL-6. Binding of IL-6 to its receptor IL-6 receptor (IL-6R) initiates activation of the JAK-STAT3 pathway. STAT3 binds directly to the proximal promoter to increase hepcidin expression. Hypoxia and erythropoiesis are inhibitors of hepcidin expression and these are the least understood pathways by which hepcidin expression is regulated. Hypoxia and erythropoiesis have been shown to inhibit hepcidin expression via direct binding of HIF to the proximal promoter, an EPO-EPO receptor (EPOR) mediated decrease in C/EBPa expression, and through increase in an unknown erythroid derived factor which signals through an undefined pathway. 


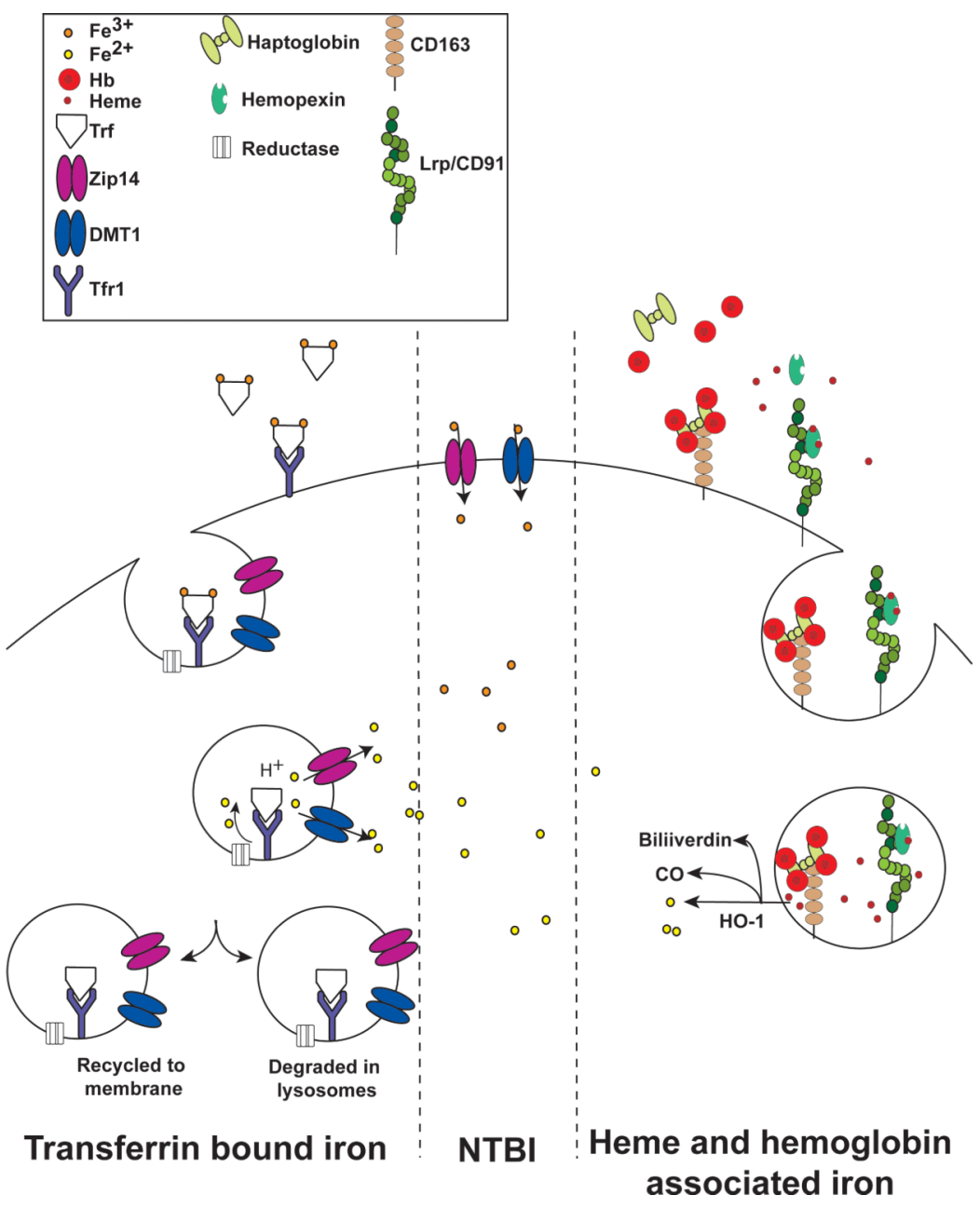

Figure 4. Mechanisms of liver iron uptake

Iron is imported into the liver via Tf/Tfr mediated endocytosis. As the $\mathrm{pH}$ of the endocytic vesicle drops, iron is released, reduced to $\mathrm{Fe}^{2+}$ by an endocytic reductase, and transported out by DMT1 and/or ZIP14. During iron overload a significant amount of NTBI is present. Iron can be directly transported into the liver through membrane bound DMT1 and/or ZIP14. During conditions of increased hemolysis the liver is capable of transport of hemoglobin and heme. Free hemoglobin binds with high affinity to haptoglobin, whereas free heme binds to hemopexin. These complexes bind to their respective receptors CD163 and Lrp/CD91, which initiate receptor-meditated endocytosis. Hemoglobin is degraded in the endosome and heme is released from the endocytic vesicle. Heme is further degraded by $\mathrm{HO}-1$ releasing iron. 
1) Catalytic Step: $\mathrm{Fe}^{3+}+\cdot \mathrm{O}_{2}-\rightarrow \mathrm{Fe}^{2+}+\mathrm{O}_{2}$
2) Fenton Reaction: $\mathrm{Fe}^{2+}+\mathrm{H}_{2} \mathrm{O}_{2} \rightarrow \mathrm{Fe}^{3+}+\mathrm{OH}^{-}+\cdot \mathrm{OH}^{-}$

3) Resulting in:

$$
\cdot \mathrm{O}_{2}^{-}+\mathrm{H}_{2} \mathrm{O}_{2} \rightarrow \cdot \mathrm{OH}+\mathrm{OH}^{-}+\mathrm{O}_{2}
$$

Figure 5. Schematic diagram of the Fenton and Haber-Weiss reactions

Iron is a potent catalytic cofactor, which increases highly unstable oxygen radicals that cause cellular damage. 


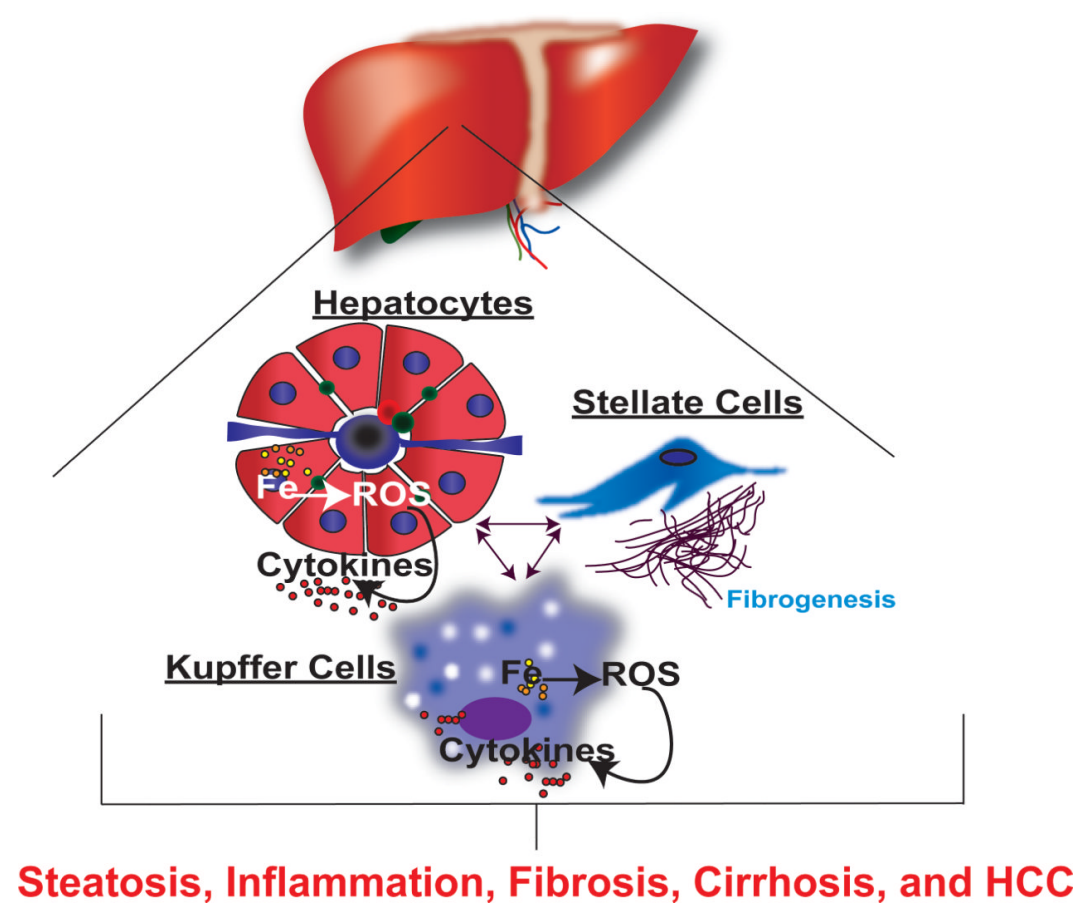

Figure 6. Iron-induced liver damage

Iron accumulation in hepatocytes and Kupffer cells leads to an increase in ROS production and pro-inflammatory mediators. Both ROS and pro-inflammatory mediators initiate a feed forward cycle, which activates stellate cells, initiates cell damage, and leads to loss of function contributing to an increase in steatosis, fibrosis, cirrhosis, and HCC. 
Table 1

Common causes of secondary hemochromatosis

Thalassemia
• a-thalassemia
• $\beta$-thalassemia minor
• $\beta$-thalassemia major
Sickle-cell anemia
Sideroblastic anemia
- Acquired
• ALAS2 deficiency
Myleodysplastic syndrome (MDS)
• Refractory anemia
• Refractory anemia with excess of blasts
- Refractory anemia with ringed sideroblasts
• Chronic myelomonocytic leukemia
• Atypical Chronic Myeloid Leukemia
- Unclassified MDS
Aplastic anemia
Pyruvate kinase deficiency
Glucose-6-phosphate dehydrogenase deficiency
Aceruloplasminemia
Dypotransferrinemia

